\title{
Deformation characteristics and multi-slab formation of a deep-seated rock slide in a high alpine environment (Bliggspitze, Austria)
}

\author{
C. Zangerl ${ }^{1} \cdot$ C. Fey ${ }^{1,2,3} \cdot$ C. Prager ${ }^{3,4}$
}

Received: 2 April 2018 / Accepted: 25 March 2019/Published online: 1 May 2019

(C) The Author(s) 2019

\begin{abstract}
This study presents the results of a more than 10-year-long field investigation and remote sensing monitoring campaign of a highly active deep-seated rock slide located in a glacial to periglacial environment (Bliggspitze, Tyrol, Austria). Data concerning (i) the terrain surface displacements based on imagery (webcam time-lapse, ortho-images) and both terrestrial and airborne laser scanning, and (ii) the geological-structural and geomorphological situation were analysed to develop a geological-geometrical model of the rock slide and to study the temporally variable activity behaviour and the formation of individual rock slide slabs. Results clearly show that at least seven rock slide slabs were formed at different times and under different slope stability conditions. Some of these rock slide slabs were displaced at slow to moderate velocities and reached scarp offsets of several tens of metres, whereas other, shallower slabs collapsed and formed extremely rapid rock falls and avalanches. Generally, the rock slide is affected by rock mass cataclasis, fracturing and loosening, which in turn cause extensive mass loss accompanied by debris accumulation at lower parts of the slope. The cause for the development of the Bliggspitze rock slide is poorly understood. However, there are clear indications that permafrost degradation and/or glacial retreat, particularly at the foot of the slide, during the recent decades may have adversely affected the slope stability situation.
\end{abstract}

Keywords Deep-seated rock slide $\cdot$ Metamorphic rock $\cdot$ Rock slide slab formation $\cdot$ High alpine environment $\cdot$ Glacial changes · Remote sensing $\cdot$ Monitoring $\cdot$ Airborne and terrestrial laser scanning

\section{Introduction}

Deep-seated rock slides, located in well-foliated, mica-rich metamorphic rock masses, are usually compound slides characterised by significant internal fracturing and distortion of the displaced mass (Hungr et al. 2014). Typical geomorphological and structural features are stepped slope profiles, horst and graben structures, and/or secondary shear zones representing distinct boundaries of rock slide slabs/blocks of individual deformation and activity characteristics. As opposed

\section{Zangerl}

christian.j.zangerl@boku.ac.at

1 Institute of Applied Geology, University of Natural Resources and Life Sciences Vienna, 1190 Vienna, Austria

2 TIWAG, Tiroler Wasserkraft AG, 6020 Innsbruck, Austria

3 alpS GmbH, 6020 Innsbruck, Austria

4 ILF Consulting Engineers Austria GmbH, 6063 Rum, Austria to the formation of "single block" rock slides, the deformation behaviour of compound rock slide systems composed of individual slabs is different and complex (Zangerl et al. 2015). Herein, "rock slide slabs" are defined as individual parts of rock/soil masses which are delimited to other parts of the slide by shear zones composed of loose and non-cemented fault breccias and gouges. Deformation accumulates predominately along these shear zones and slope activity may vary from slab to slab. Generally, the development of individual slabs represents the slope stability evolution over time and leads to a considerable increase in complexity with regard to the kinematical, geomechanical and hydrogeological properties of a rock slide (Strauhal et al. 2017). Interaction with adjacent slope sections, displacement of rock slabs and soil deposits (e.g. new talus accumulation) cause ongoing slope processes which are generally difficult to characterise and quantify. It is even more challenging to numerically simulate such phenomena for process analyses, hazard assessments and mitigation measures. For numerical modelling, the complex mechanical interaction of different active slabs arranged on top of and/or laterally to 
each other have to be considered and often modelled in combination with large discrete shear displacements. Conceptually, this complex geomechanical behaviour has a considerable impact on the overall slope stability, and an understanding of such rock slide processes is crucial for risk and hazard assessment. Key issues concerning the failure and deformation behaviour of such rock slides require comprehensive investigation and prediction methods. Hence, there is a difference between a large rock slide that fails extremely rapidly as a whole in a single high-magnitude event, potentially developing a long runout path, and one that subdivides into smaller individual slabs that interact but do not fail synchronously as an entire mass. In the latter case, the failure of individual rock slide slabs is temporally different, i.e. not characterised by the collapse of the entire slope, but by sequential mobilisation of much smaller individual volumes (slabs). As such, even if such slabs fail rapidly as rock avalanches, but successively one slab after the other, a collapse is characterised by much shorter runout lengths (Willenberg et al. 2008). Such failure and runout behaviour may be expected and predicted based on the empirical correlation between failure volume and runout length (e.g. Heim 1932; Scheidegger 1973; Körner 1976; Okura et al. 2000; Legros 2002; Prager 2010). According to Hungr et al. 2014, the term "rock avalanche" is applied herein to failure events, independent of the landslide volume, characterised by extremely rapid flow-like motion of fragmented rocks featuring strong mechanical interaction between the displaced rock fragments. This is in contrast to rock fall events occurring singly or in clusters and interacting mainly with the substrate but having little dynamic interaction between the moving fragments. The increased internal fracturing, fragmentation and loosening of the rock mass during slope deformation and slab formation can produce considerable amounts of loose soil that freshly accumulate as talus at the foot of the slope (scree, rock fall and rock avalanche deposits). Conceptually, this material erosion and accumulation changes the slope geometry and the in situ stress conditions and thus modifies the overall slope stability.

Additional complexity may arise when deep-seated rock slides are located in permafrost regions characterised by icefilled fractures and rock mass temperatures below the freezing point. Furthermore, the stability condition of a rock slope can be affected by the geomechanical and hydrogeological interaction with glaciers at the lower part or foot area of a potentially unstable slope. Glacial retreat and thawing permafrost influence the strength properties, the in situ stress conditions by unloading and the hydrological setting of a fractured rock mass (e.g. Davies et al. 2001; Deline et al. 2015; Krautblatter et al. 2013). Consequently, an increase in the instability of rock slopes in permafrost (e.g. Fischer et al. 2012; Huggel 2009; Paranunzio et al. 2016; Ravanel and Deline 2011) and recently de-glaciated areas (e.g. Cossart et al. 2008; McColl 2012; Deline et al.
2015) is observed. However, a full understanding of the processes and triggers leading to the formation and deformation of deep-seated rock slides in a glacial/periglacial environment is still lacking, and further research is needed (Ballantyne 2002; Evans and Clague 1994; McColl 2012; McColl and Davies 2013; Riva et al. 2018).

In order to assess a rock slide and monitor the slope evolution and deformation behaviour (i.e. spatial extent, 3D geometry, kinematics, location and shape of shear zones, slab formation, rock mass fragmentation and debris accumulation), mapping, rock mass characterisation, groundwater and multitemporal 2D/3D deformation data are essential. These data can be obtained from different in situ methods, such as geomorphological and geological mapping, geophysical surveys, geodetic monitoring, and borehole drilling with geophysical logging, hydraulic packer testing, and inclinometer as well as piezometer measurements. Exemplarily, comprehensive rock slope investigations were performed at the Randa landslide in Switzerland (Willenberg et al. 2008; Gischig 2011), La Saxe in Italy (Crosta et al. 2014), La Clapiere in France (Palis et al. 2017), and in the Kaunertal valley in Austria (Strauhal et al. 2017; Zangerl et al. 2010, 2015). Although extremely useful and often a requirement for a comprehensive rock slide investigation campaign, these direct methods are costly and require direct access to the slide. In high mountain areas with harsh conditions, poor and dangerous accessibility, direct site investigation and monitoring is often hardly feasible or can be done only under enormous expenses. Therefore, the assessments of the Bliggspitze site presented herein have been based on geological field surveys and extensive remote sensing. In general, remote sensing techniques provide contactless tools for investigating both geomorphological and geological features (e.g. Abellán et al. 2014; Dewez et al. 2016; Wichmann et al. 2018) and to monitor surface displacements in 2D and 3D (e.g. Delacourt et al. 2007; Scaioni et al. 2014). In contrast to other techniques, a major advantage of remote sensing techniques is that site assessments and monitoring can be performed even at inaccessible areas and/or hazard zones (Jaboyedoff et al. 2009; Oppikofer et al. 2008; Oppikofer et al. 2011; Sturzenegger and Stead 2009).

The Bliggspitze rock slide is a deep-seated compound rock slide in fractured metamorphic rock located in the inner Kaunertal valley (Tyrol, Austria, Figs. 1 and 2) and was firstly recognised in early summer 2007. During this time, increased rock fall activity originating from the northern slope of the Bliggspitze peak indicated a deep-seated slope instability. This study presents the results of a more than 10-year-long field investigation and remote sensing monitoring campaign. Geological-geomorphological field surveys and multitemporal remote sensing data were analysed, with a main focus on (i) the geological characterisation, predisposition, initial formation and temporal evolution of the rock slide, (ii) the formation and displacements of different rock and soil slide 
Fig. 1 Ortho-image from 2015 showing the location of the Bliggspitze rock slide, the positions of the terrestrial laser scanner and the webcam (Orthoimage from Federal State of Tyrol)

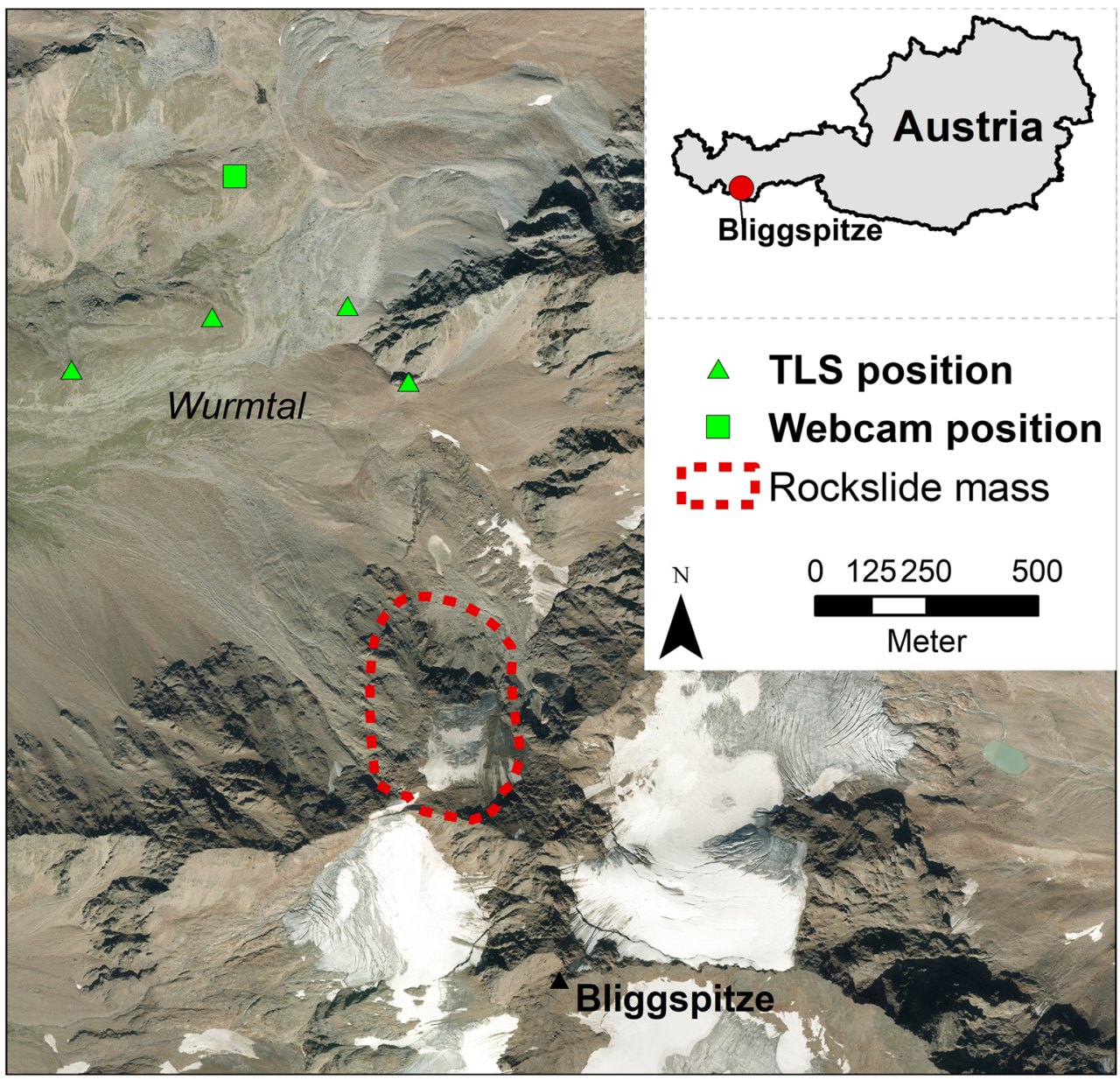

slabs, rock falls and rock avalanches, (iii) the development of a geological-geometrical rock slide model comprising slabs and both internal and basal shear zones, and (iv) the documentation of glacial retreat during recent decades and permafrost occurrence at the rock slide area. All data and models presented herein serve as a basis for subsequent studies by applying 2D/3D numerical modelling techniques to investigate the impact of glacial retreat, permafrost degradation and mass wasting on the temporal variable slope stability.

\section{Available data}

After the first site visits since summer 2007 (Zangerl et al. 2010), a geological-geomorphological map of the study area at a survey scale of 1:4000 was produced by field mapping campaigns in summer 2011 and 2012 (Dejean de la Bâtie 2016). Shaded relief images derived from airborne laser scanning (ALS), digital elevation models (DEMs) and orthoimages were used to map lithological units, geomorphological features including primary and secondary scarps, up-hill facing scarps, extensional fractures, and geological structures comprising foliation, meso-scale fractures and brittle faults.
In addition, hydrogeological data including the location and physical parameters (i.e. temperature, flow rate, electrical conductivity) of springs and streams were gathered. A direct mapping of the rock slide mass was only possible at the higher slope section near the head scarp. There, geological and geomorphological structures and permafrost indicators (i.e. icefilled fractures) are well exposed and accessible. Loose and uncemented fault gouge and breccia samples of a brittle fault zone were taken for laboratory analyses to obatin the grain size distribution, the mineralogy (powder X-ray diffraction) and the shear strength properties (ring shear tests) (Strauhal 2015). Beside visual inspections, the occurrence of permafrost was investigated by measuring the bottom temperature of the snow cover (BTS) (Haeberli 1973; Hoelzle 1992; Keuschnig 2016) by using 23 temperature loggers placed in open fractures around the head scarp. As long as these loggers are covered by snow and thus are insulated against air temperature and solar radiation, they provide temperature data as a proxy for the occurrence of permafrost (Keuschnig 2016). The loggers recorded the temperature every $2 \mathrm{~h}$ between September 2013 and September 2016.

In order to investigate slope kinematics, slab formation and temporally variable deformation behaviour, remote sensing 
Fig. 2 Photographs of the Bliggspitze rock slide (taken on 14.10.2007) showing: a an overview from the west indicating the head scarp and the boundary of the rock slide (red line), the red arrow points to a rock outcrop where no slope displacements were measured; $\mathbf{b}$ the divided Bliggferner glacier at the head scarp with the exposed failure surface; $\mathbf{c}$ the exposed failure surface, i.e. basal shear plane at the head scarp (slab A) formed along the moderately northdipping striated fault plane; $\mathbf{d}$ the fractured and fragmented rock mass of slab A; and e ice-filled fractures in the surroundings of the head scarp (11.08.2013)
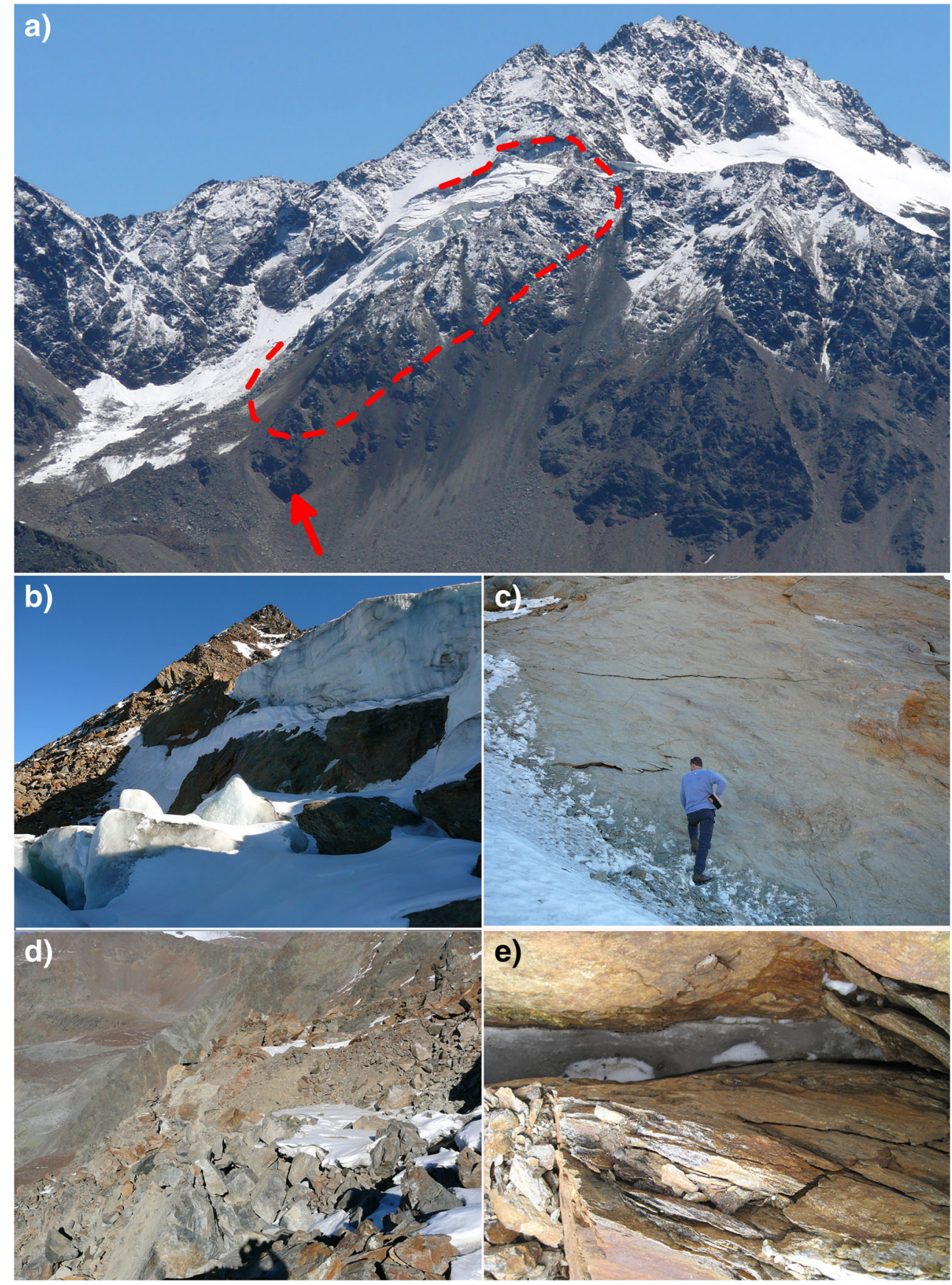

data based on airborne (ALS) and terrestrial laser scanning (TLS) and imagery were analysed (Table 1). Between 2006 and 2012, the terrain was monitored by annual ALS surveys. For a detailed description of the data quality, accuracy and processing steps, see Fey et al. 2015 and Fey 2018. Due to ongoing slope deformations, the monitoring program was enhanced by TLS surveys performed annually since 2014 (Fey et al. 2017a). Therefore, the rock slide was scanned with a long-range terrestrial laser scanner from three scanning positions located at topographically appropriate and safe positions (i.e. small ridges) at the foot of the slope (Fig. 1).
In addition, images taken by two Mobotix M22 webcams (Fig. 1) provided valuable information concerning the temporal evolution of the rock slide. The two webcams were installed by Federal State of Tyrol in September 2007 at the foot of the slope and programmed to take three images per day, which were transmitted by a modem and thus quickly available online. The cameras were installed and configured in such a way that one camera captures the total overview of the rock slide and the other one captures a detailed view of the upper slope section.

Temporal and spatial changes of the Bliggferner glacier were assessed by analyses of historical topographical maps 
Table 1 Remote sensing data used for the Bliggspitze rock slide analyses

\begin{tabular}{|c|c|c|}
\hline Data source & Date of release & Information (relevance for the Bliggspitze area) \\
\hline $\begin{array}{l}\text { Historical topographic maps (Alpine Clubs, } \\
\text { DAV, ÖAV) }\end{array}$ & 1893, 1946, 1969, 1997, 2006 & $\begin{array}{l}\text { - Reconstruction of Bliggferner ice retreat and assessment of } \\
\text { glacier volume changes }\end{array}$ \\
\hline $\begin{array}{l}\text { Ortho-images } \\
\text { (Federal State of Tyrol) }\end{array}$ & $2003,2007,2009,2010$ & $\begin{array}{l}\text { - Assessment and mapping of terrain units (e.g. bedrock, } \\
\text { soils, structural and morphological, glacial ice) } \\
\text { - 2D measurement of terrain surface changes } \\
\text { - Visual assessment, interpretation of rock slide processes }\end{array}$ \\
\hline $\begin{array}{l}\text { ALS data } \\
\text { (Federal State of Tyrol/TIWAG) } \\
\text { TLS data } \\
\text { (Fey et al. 2017a) }\end{array}$ & $\begin{array}{l}\text { 2006, 2007, 2008, 2009, 2010, } 2012 \\
\text { 2012, 2014, 2015, } 2016\end{array}$ & $\begin{array}{l}\text { - Identification and quantification of } 2 \mathrm{D} / 3 \mathrm{D} \text { surface } \\
\text { displacements, generation of displacement and distance } \\
\text { change maps } \\
\text { - Identification and quantification of mass relocations } \\
\text { (mass loss and accumulation) } \\
\text { - Analyses of geomorphological and structural features }\end{array}$ \\
\hline $\begin{array}{l}\text { Webcam images } \\
\text { (Federal State of Tyrol) }\end{array}$ & $2007-2016$ & $\begin{array}{l}\text { - Visual analyses and interpretation of slope deformation } \\
\text { processes (based on time-lapse image sequences) }\end{array}$ \\
\hline Terrestrial images from field investigation & 2003, 2007, 2009, 2011 & $\begin{array}{l}\text { - Visual analyses and interpretation of slope deformation } \\
\text { processes }\end{array}$ \\
\hline
\end{tabular}

of the Austrian and German Alpine Clubs (maps dated 1893, 1946, 1969 and 1997, see Table 1).

\section{Methods}

Before deformation analyses were performed, the ALS and TLS raw data were pre-processed and transformed into a common coordinate system by using a relative registration and geo-referencing approach (Fey 2018). The ALS point cloud from 2012 available in the global coordinate system (ETRS 89 UTM $32 \mathrm{~N}$ ) was defined as a reference point cloud, and all subsequent point clouds were matched onto this reference point cloud by the use of an iterative closest point algorithm (ICP). Registration of the TLS scans was done using an ICP algorithm implemented in RiSCAN Pro (Riegl 2013). The individual TLS scans were matched onto stable areas (i.e. areas which have not been modified by geomorphological and geological surface processes) of the reference point cloud from 2012. For slope deformation analyses, the precise relative alignment of two data sets is more important than the precise absolute geo-referencing. Therefore, the georeferencing of the ALS point clouds was revised with the aim to increase the relative accuracy of the data sets (Fey 2018; Fey et al. 2015). A transformation matrix was derived by matching the stable areas of the respective ALS point cloud onto the reference point cloud (ALS scan from 2012) using an ICP algorithm implemented into OPALS (Pfeifer et al. 2014; Glira et al. 2015). Then, the transformation matrix was applied to the entire ALS point cloud data sets.

After the pre-processing step, ALS and TLS data were analysed focusing on both types of surface deformation analyses, i.e. slope displacement and distance change analyses, respectively. These deformation analyses were performed by applying the software SAGA GIS and the SAGA GIS add-on LIS Tools (www.laserdata.at, 2018). For displacement analyses, the distance between homologous parts detected in two data sets is measured by the identification of corresponding surface elements (e.g. terrain ridges or rock slide slabs, Fey 2018). Displacement analyses are used to quantify the amount of the 2D/3D displacement and the displacement direction of rock slide slabs. The displacement analyses are based on two techniques, i.e. the break line tracking and the image correlation method (Fey et al. 2015). For both methods, the point cloud data set was triangulated to a digital elevation model (DEM). Breakline tracking was used to analyse surface displacement processes accompanied by strong structural terrain changes. Break-line tracking is based on the identification of displacements of terrain ridges and depression structures which can be located on the two images. The ridge and depression structures are derived from curvature images calculated from ALS DEMs and then automatically skeletonised to break lines. Junction points of break lines were used to track manually the displacement of ridge and depression structures (Fey et al. 2015).

In contrast to break-line tracking, image correlation-based displacement analyses are less time-consuming, and can be used to analyse the spatial displacement behaviour of rock slide slabs. The principle of image correlation is based on the detection of corresponding features by a pattern search algorithm that detects similar textures in the two images from different epochs (Fey et al. 2015; Fey et al. 2017a, 2017b). In this study, we used shaded relief images with a non-direct lighting method (ambient occlusion, Tarini et al. 2006), where all objects are diffusely illuminated (comparable to a cloudy day) and thus without the appearance of distinct shadows and very bright objects. The advantage of ambient occlusion shaded relief images is that all objects are displayed independently from the lighting direction and that no objects are hidden by 
shadows (Fey et al. 2015). If the surface texture has been destroyed due to rockfall, structural changes or erosion from one image to the next, no or only wrong correlations occur. Such miscorrelations were identified by analysing the displacement vector pattern. Within the search window vectors from miscorrelations are pointing in all directions and the vector lengths vary strongly (Fey et al. 2015; Fey et al. 2017a, 2017b). For the identification of miscorrelations, a level of detection (LoD) was defined to distinguish between real terrain changes and measurement uncertainties. The LoD applied for the displacement analyses is based on the standard deviation of displacements, which were measured in areas without terrain changes. If the measured displacement is below the LoD, the value was not used for further analyses (Table 2). The vector fields resulting from image correlation analyses were used to identity and delimit rock slide slabs showing different activity and also to determine the displacement direction and velocity of the slabs.

As opposed to displacement analyses, distance change analyses quantify the distance between the pre- and postfailure terrain surface or between different post-failure terrain surfaces. The approach used for distance measurements (Fey and Wichmann 2017) is point cloud based, fully 3D and robust against surface roughness and low point densities. In contrast to elevation differences calculated from raster DEMs, the 3D distance measurement approach (Fey and Wichmann 2017) measures distances in 3D in the direction of a normal of a tangent plane which is fitted to the surface. Thus, the 3D distance measurement approach does not necessarily calculate the distance along an axis in the vertical direction. The LoD used for distance change analyses (Table 2) is based on a confidence interval considering spatially variable positional uncertainties, local surface roughness and registration errors (Fey and Wichmann 2017). The distance change maps were used to identify slope areas affected by (i) extremely rapid failure processes such as rock falls and rock

Table 2 Level of detection (LoD) of displacement and distance change analyses (Fey 2018)

\begin{tabular}{llll}
\hline \multirow{2}{*}{ Time period } & Data source & \multicolumn{2}{l}{$\operatorname{LoD}[\mathrm{m}]$} \\
\cline { 3 - 4 } & & Displacement analyses & 3D Distance change \\
\hline $2007-2006$ & ALS - ALS & $0.36^{*}$ & $0.41-0.95$ \\
$2008-2007$ & ALS - ALS & $0.31^{*}$ & $0.53-1.08$ \\
$2009-2008$ & ALS - ALS & $0.26^{*}$ & $0.45-0.98$ \\
$2010-2009$ & ALS - ALS & $0.23^{*}$ & $0.43-0.98$ \\
$2010-2012$ & ALS - ALS & 0.21 & - \\
$2012-2014$ & ALS - TLS & 0.50 & $0.49-0.74$ \\
$2014-2015$ & TLS - TLS & 0.26 & $0.16-0.61$ \\
$2015-2016$ & TLS - TLS & 0.08 & $0.11-0.60$
\end{tabular}

*The LoD values differ from the values presented in Fey et al. (2015) because the geo-referencing was updated by relative ICP matching avalanches, (ii) accumulation of soil deposits (i.e. debris generated from slope processes), and (iii) terrain surface lowering and uplift due to slope deformation processes.

In addition to laser scan data, multi-temporal ortho-images with spatial resolutions of 0.25 and $0.2 \mathrm{~m}$, respectively, were analysed (airborne surveys, dated 2003, 2007, 2009 and 2010, see Table 1). The visual analyses and interpretation of orthoimages enabled the identification and documentation of slope changes, comprising the formation of new slabs and scarps, glacier cover and its changes, spatial distribution of rock outcrops and accumulation of debris at the time of image acquisition.

Selected webcam recordings were used to generate timelapse image series for selected periods of interest, i.e. phases of intensified slope activity. These time-lapse analyses enabled a comprehensive reconstruction and visualisation of deformation processes such as the formation of new scarps, opening of extensional cracks, formation of new sliding slabs, rock/debris falls and slides. It should be noted, however, that these time-lapse analyses were sensitive to and limited by bad weather conditions (strong wind, snow fall, fog).

In addition, photographs taken during the numerous field campaigns since 2007 were analysed for the reconstruction and analyses of slope processes.

The reconstruction of the glacial retreat is based on historical topographical maps. In a first step, the historical maps were scanned, rectified and georeferenced, and the elevation lines of these maps were digitised and interpolated. In a second step, DEMs with a resolution of $20 \mathrm{~m}$ for a certain survey time were produced and used to calculate glacier change maps between two periods. In a third step, glacier volume changes were assessed by calculating DEM differences and multiplying the summarised raster cells of the DEM differences with the raster cell size.

\section{Geological and (peri-)glacial characterisation}

The Bliggspitze rock slide is situated in the poly-metamorphic Ötztal-Stubai basement complex, a major Austroalpine thrust unit, which is composed mainly of $\mathrm{E}-\mathrm{W}$ striking layers of paragneisses, mica schists, orthogneisses and amphibolites (Hammer 1922; Purtscheller 1987; Schmid et al. 2004). During the Holocene, i.e. several thousand years after the Last Glacial Maximum (LGM), several deep-seated rock slides were formed in the Kaunertal valley region (Strauhal et al. 2017; Zangerl et al. 2010; Zangerl et al. 2015). Like many rock slides in this region, the Bliggspitze rock slide originated in mica-rich meta-sedimentary rocks (i.e. paragneissic rock series) made of a compositional layering of gneisses, quartzites and mica schists (Figs. 2 and 3). These rock types are mainly composed of varying contents of quartz, plagioclase, alkali-feldspar, biotite and muscovite. 


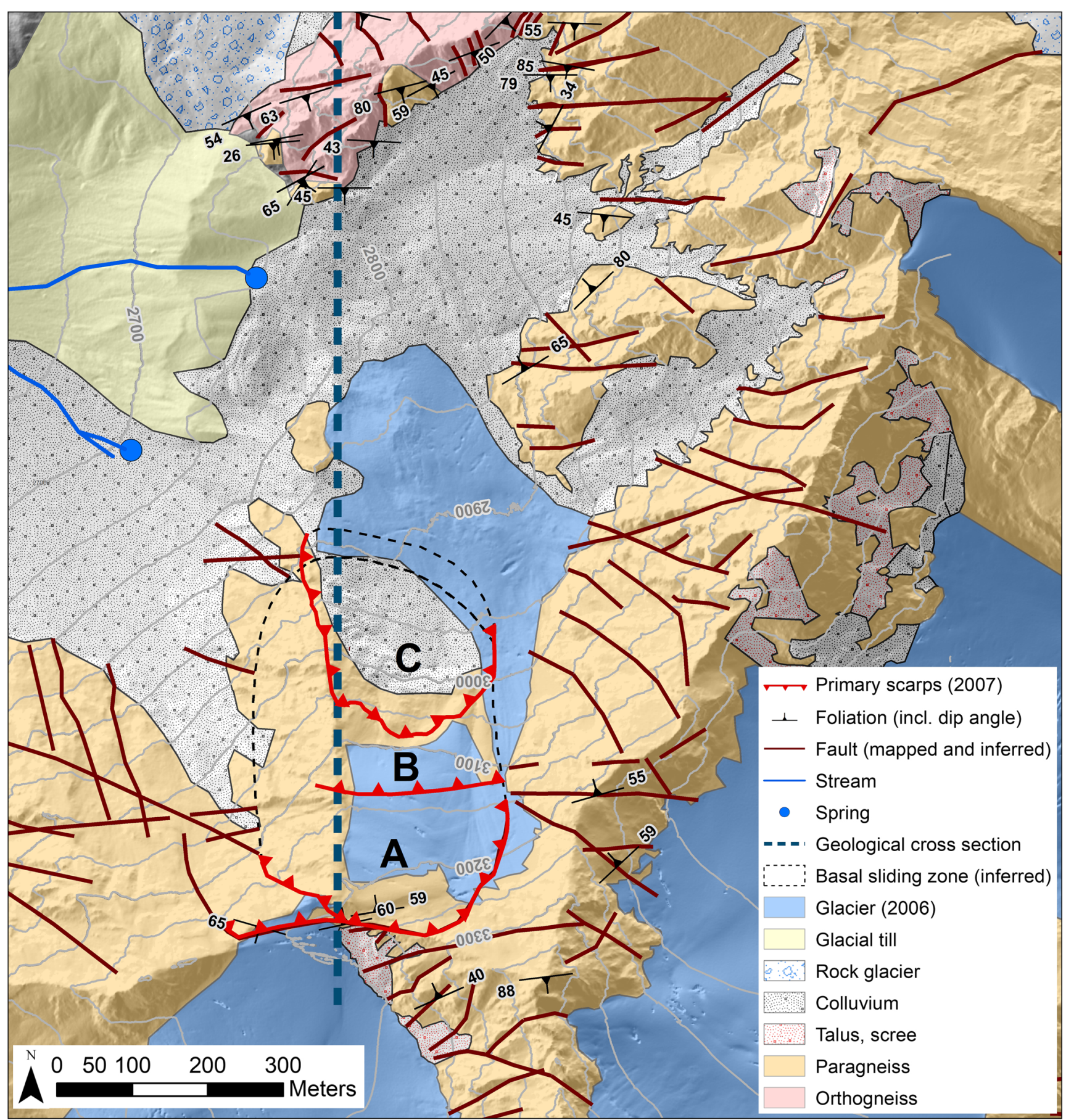

Fig. 3 Geological overview map of the study site (Dejean de la Bâtie 2016 and own field data)

Texturally, the paragneissic rock shows a penetrative foliation formed by the sub-parallel alignment of mica grains embedded in a matrix of quartz/plagioclase (Dejean de la Bâtie 2016). At meso- to large-scale, the compositional layering and the foliation planes are folded, forming an open synform with an E-W striking, flatly inclined fold axis in the rock slide area (Fig. 3). Lithologically, the southern limb of the synform is composed of paragneissic rock, whereas the northern limb is composed of granitic orthogneisses. The rock slide itself is located in the southern limb characterised by foliation planes dipping moderately towards N-NW, i.e. somewhat forming structurally a pre-disposed dip-slope geometry (Fig. 3).

Concerning the brittle tectonic overprint of the area, some distinct brittle faults striking $\mathrm{E}-\mathrm{W}$ to NE-SW and dipping steeply to moderately $\mathrm{N}$ and NW, respectively, were mapped (Fig. 2c). Faults were mapped in situ by field surveys and by GIS-based lineament mapping on ortho-images and ALSshaded relief images. Brittle fault zone cores show either 
$\mathrm{mm}$ - to dm-thick zones of cemented cataclasites or loose uncemented fault gouges and breccias, with adjacent rims of increased fracture densities (i.e. fault damage zones, e.g. Strauhal et al. 2017). On several brittle fault planes, tectonically formed slickenside striations were observed (Fig. 2c). The head scarp of the Bliggspitze rock slide is formed along a prominent brittle fault plane dipping moderately towards $\mathrm{N}$ (i.e. mean fault dip direction/dip angle of 348/44). Slickenside striations on this fault plane are dipping with a mean trend/plunge of 309/36 oblique to the fault dip, and thus could not be related to the rock slide formation process. One prominent E-W-striking steeply dipping brittle fault zone extends from the stable bedrock outside of the slide into the rock slide and separates the rock slide into two parts, later defined as the upper rock slide "slab A" and lower "slab B" (Fig. 3). In order to characterise such brittle faults, a sample of fault zone material was taken near the main scarp at an altitude $3170 \mathrm{~m}$ a.s.l and investigated with regard to the grain size distribution, mineral content and shear strength properties. Mineral analyses based on X-ray powder diffraction (XRPD) and the standard Rietveld method show compositions of $28 \%$ quartz, $27 \%$ plagioclase, $3 \%$ alkali-feldspar, $25 \%$ mica (including both biotite and muscovite) and $17 \%$ chlorite (RVS 11.062 1987). This mineralogical composition is similar to that generally observed in the paragneissic host rock, and it was found that here, clay minerals were usually not formed from the host rock due to weathering or alteration processes (Hammer 1922; Purtscheller 1987).

Polyphase tectonic processes fractured the folded and foliated rock mass and generated a meso-scale joint pattern (e.g. Purtscheller 1987; Schmid et al. 2004). In the upper part of the rock slide, four dominant joint sets were mapped (Fig. 4): set \#1 is steeply inclined and strikes $\mathrm{E}-\mathrm{W}$, set \#2 is dipping steeply towards NE, set \#3 is dipping steeply towards NW, and set \#4 is dipping moderately towards E. Remarkably, flat and moderately to $\mathrm{N}$-dipping joints were not measured frequently, at least around the head scarp area.
Analyses of topographic maps from Alpine Clubs, orthoimages from archives and multi-year geological field surveys (Piccolruaz 2004; Dejean de la Bâtie 2016; Fey 2018) were used to document the glacial retreat in recent decades. Concerning the glacial history, during the Last Glacial Maximum (LGM, Würmian) the Kaunertal valley, including the Bliggspitze region, was filled with thick glacial ice, with the ice surface of the main valley glaciers extending to elevations of above $2800 \mathrm{~m}$ a.s.l, and with the highest summits and ranges towering Nunatak-like as glaciated highpoints (van Husen 1987). These glacial extents and the elevation of the present-day valley floor west of the Bliggspitze, i.e. underneath the Gepatsch reservoir dam at approx. $1700 \mathrm{~m}$ a.s.l., indicate here an LGM ice thickness of around $1000 \mathrm{~m}$ (for location see Zangerl et al. 2010). It has to be mentioned that the exact LGM ice thickness in this region has not been assessed so far. However, concerning the Eastern Alps, compiled data indicate that Late Pleistocene glaciers retreated rather rapidly, reaching modern extents for the first time at about $950014 \mathrm{C}$ years BP, i.e. approx. 10,850 cal. years (Ivy-Ochs et al. 2009; Patzelt 1972, 1977). In the central Stubai Alps (Tyrol, Austria), slopes were already re-forested at elevations of approx. $2100 \mathrm{~m}$ a.s.l. at about $960014 \mathrm{C}$ years BP, i.e. approx. 10,950 cal BP, (Bortenschlager 1984; Weirich and Bortenschlager 1980). During and after the decay of the LGM glaciers, major glacier fluctuations are documented in the surroundings of the Bliggspitze area (Gepatschferner glacier) for the Late Glacial and Holocene periods (Kerschner 1979; Kerschner and Nicolussi 2014; Nicolussi and Patzelt 2000). For example, after the deposition of Late Glacial moraines, some are well preserved at approx. 2200 to $2400 \mathrm{~m}$ a.s.l.; the Gepatschferner glacier terminated at its last Little Ice Age (LIA) with a maximum position in AD 1856 at $1890 \mathrm{~m}$ a.s.l. From there, the glacier has been generally retreating, but interrupted by two minor re-advances in the twentieth century (Kerschner \& Nicolussi 2014). In this way, several present-day glaciers in the Eastern Alps have
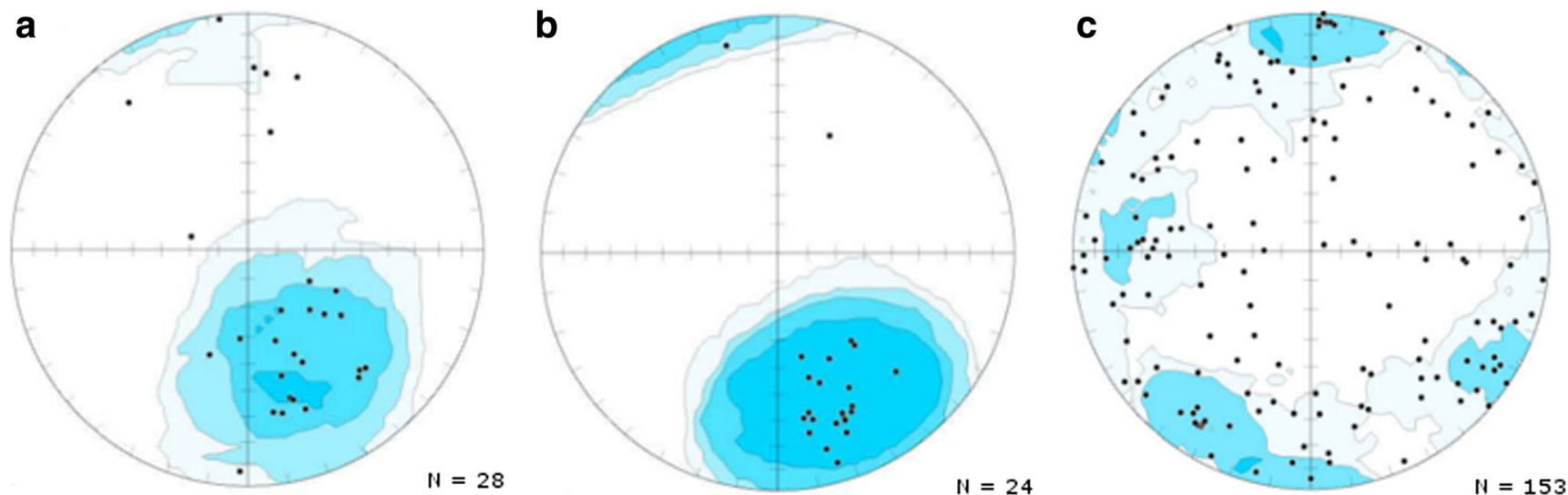

Fig. 4 Lower hemisphere stereographic contour plot of poles: a foliation planes in the head scarp area, b brittle fault planes showing slickensides striations, and $\mathbf{c}$ meso-scale fractures in the surroundings of the rock slide area 
been affected by significant climate change-related retreats. After the last historic glacial high stand in AD 1850, the present-day glaciers indicate significant climate changerelated retreats (e.g. Fischer et al. 2015). Similar observations were made at the Bliggferner glacier, where at the northern and western slope of the Bliggspitze summit, remarkable ice losses were measured by calculating terrain differences between an ALS-based DEM (2006) and a DEM, obtained from a historical topographical map (1946). Figure 5 shows the glacial retreat and ice mass loss for this 60 -year period, indicating an ice thickness reduction of several tens of metres with a maximum of up to $50 \mathrm{~m}$.

Permafrost-related ice has been observed in fractures at the head scarp area of the Bliggspitze rock slide (Fig. 2e). Permafrost occurrences were also documented by field measurements based on the basal temperature of snow (BTS), i.e. measured at the contact between terrain surface and snow cover (Fig. 5). BTS data show from February to April, when the snow cover reaches its maximum thickness and the insulation from the snow cover protects the temperature loggers from atmospheric influences, a temperature decrease to $-3^{\circ}$ to $-5{ }^{\circ} \mathrm{C}$ (Fig. 6). According to literature, BTS below $-3{ }^{\circ} \mathrm{C}$ indicates that permafrost is probable (Hoelzle 1992). Later in the year, BTS temperatures increase to $0{ }^{\circ} \mathrm{C}$ in May and June, which is related to a decreasing snow cover thickness and to discharge/infiltration of meltwater. After snowmelt during
July and August, BTS temperatures further increased to higher temperatures, greatly exceeding $0{ }^{\circ} \mathrm{C}$, and strong fluctuations occurred. During this period, the loss of insolation by snow cover and the direct influence of air temperature became relevant.

\section{Rock slide formation and deformation characteristics}

In June 2007, at the northern slope of the $3453 \mathrm{~m}$ high Bliggspitze summit, numerous gravitational slope processes comprising rock/ice falls, rock avalanches and rock slides were observed. The remarkable high number of small-scale rock fall events were triggered by the first-time formation of a deep-seated rock slide causing the destabilisation of the whole $\mathrm{N}$-dipping rock slope. In this chapter, remote sensing data from surveys over the past decade were analysed to develop a comprehensive chronological sequence of the rock slide processes. Data obtained from imagery and ALS/TLS campaigns allow the (i) reconstruction of the pre-failure situation, (ii) the spatial determination of scarps and individual rock slide slabs, (iii) the determination of slope displacements and their changes over time, (iv) the delimitation of the rock slide, and (v) the delimitation of the ice coverage. In order to reconstruct and analyse the slope processes and slab formation over

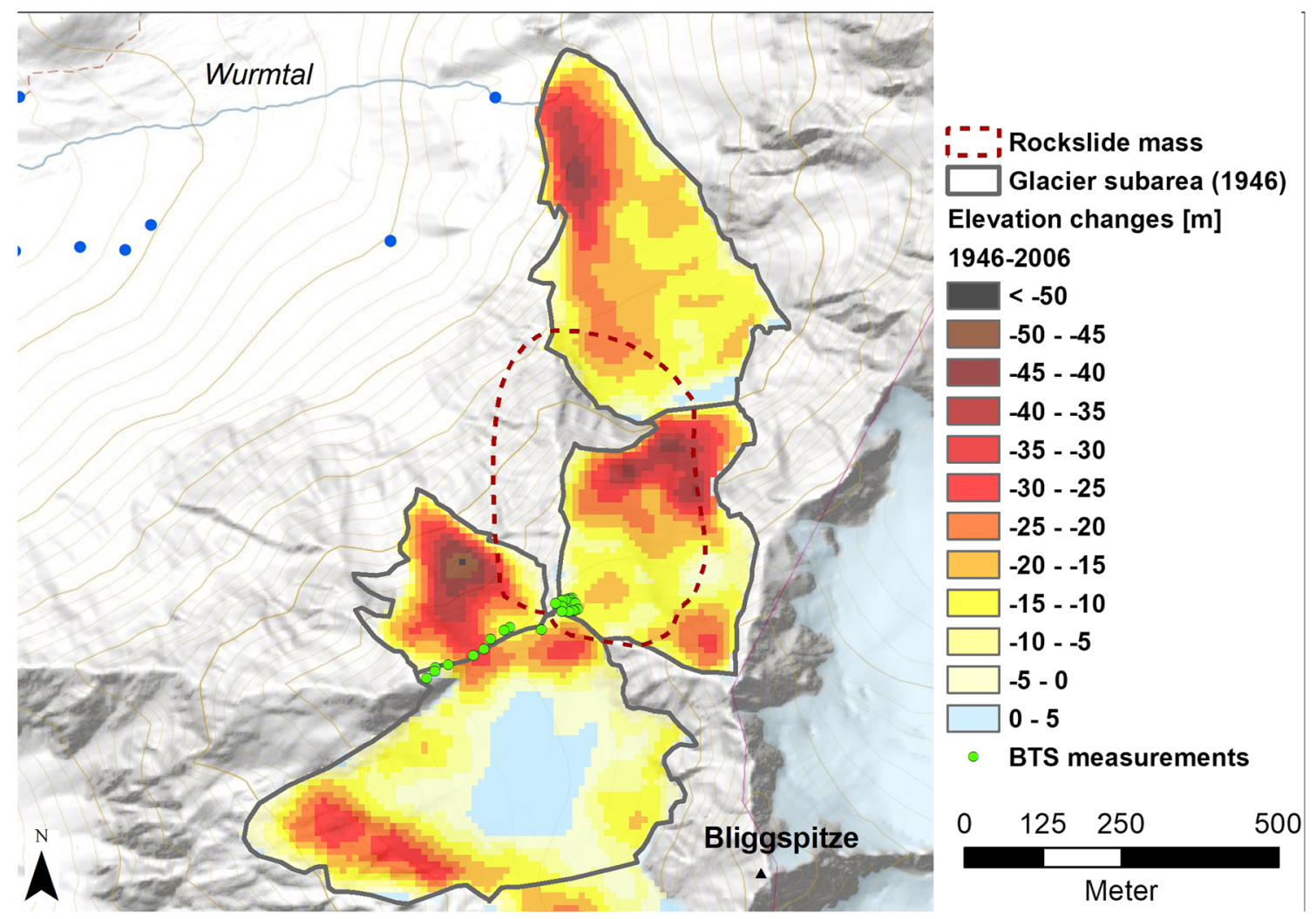

Fig. 5 Representation of the spatial extent of the Bliggferner glacier in the year 1946, the resulting thickness changes between 1946 and 2006 , and the location of BTS measuring devices (green dots) 


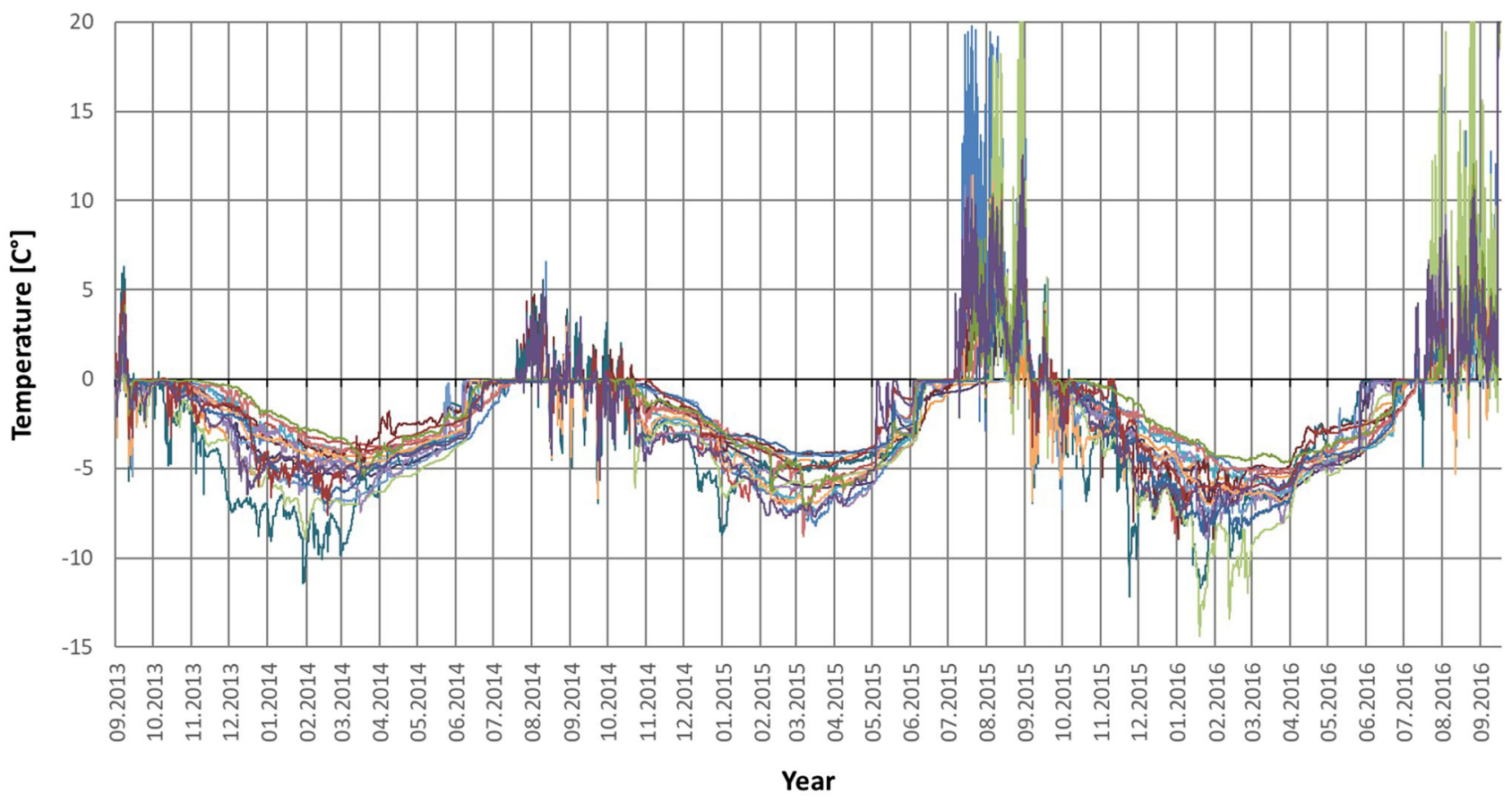

Fig. 6 BTS measurements in the surroundings of the head scarp (3270 m a.s.1.) during September 2013 and September 2016 (for locations see Fig. 5)

the course of time, in the following section, selected periods were described in detail and presented in Fig. 7. The entire temporal evolution of the rock slide is shown and summarised in Fig. 8.

\section{Period 2006 to 2007: Beginning of slope activity and formation of rock slide slabs $A, B, C$ and $E$}

Analyses of the ALS data pair 2006/2007 and the orthoimage pair 2003/2007 shows that the rock/soil mass of the slope is characterised by intensive fracturing, loosening, displacement and accumulation (Figs. 7a and 8). During this deformation stage, a head scarp was formed at an elevation of about $3270 \mathrm{~m}$ a.s.l. A special feature observed in the field in October 2007 was the formation of the head scarp along the moderately $\mathrm{N}$-dipping fault plane (see chapter 4), that offsets the Bliggferner glacier in the crest region (Figs. 2b, c and 3, Zangerl et al. 2010). Thus, the formation of the rock slide head scarp caused a separation of the glacier into two separate parts near the ridge (Fig. 2a, b). Detailed ALS analyses indicated a terrain surface lowering of up to $36 \mathrm{~m}$ near the fault plane (Fig. 7a). This rock slide mass represents the uppermost part where slope deformation occurred, herein referred to as "slab A", and is exposed down to an elevation of about $3120 \mathrm{~m}$ a.s.l. In the head scarp region, breakline tracking-based displacement analyses (Fey et al. 2015) show total 3D displacements of about $40 \mathrm{~m}$ (Fig. 9). Such displacements are in agreement with field observations indicating a shear offset along the brittle fault plane of up to 40 $\mathrm{m}$. The dip angle of the total 3D displacement vector is about $45^{\circ}$, and thus coinciding with the mean dip angle of the basal shear surface (moderately to $\mathrm{N}$-dipping fault plane) exposed in the head scarp area. To the west, slab A borders to a NW-dipping deep trough. Before the onset of the increased rock slide activity, the upper section of this trough was filled with glacial ice reaching AD 1946, a more than $50 \mathrm{~m}$ thick ice wedge (Fig. 5). Presently, this ice layer has almost totally melted. ALS data indicate a spreading of the rock slide mass towards NW, most likely as a result of internal rock mass deformations (Fig. 7a). The measured rock mass deformation is manifested by an area of increased rock mass accumulation reaching 5 to $20 \mathrm{~m}$ and by displacement vectors of slab A dipping towards N-NW.

In north direction, the extension of slab $\mathrm{A}$ is limited by a E$\mathrm{W}$-striking, steeply inclined fault crossing the slope at a height of about $3120 \mathrm{~m}$ a.s.l. As already mentioned in section 4, it is suggested that this persistent fault plane subdivides the rock slide body into two slabs: slab A, located upslope of this fault, and slab B downslope (Fig. 3). Due to the ice cover, the scarp of slab B is for the most part not directly exposed.

An additional new slab, herein termed slab C, was formed at an elevation around 2930 and $3050 \mathrm{~m}$ a.s.l., downslope of slab B (Figs. 7a and 8). Formation of slab $\mathrm{C}$ was accompanied by the development of a distinct scarp surface which was initially noticeable by the opening of a long crack (i.e. scarp surface), encountered along the whole width of the unstable slope. The time of the initial failure process, characterised by the evolution of the scarp, can be determined by the ortho- 

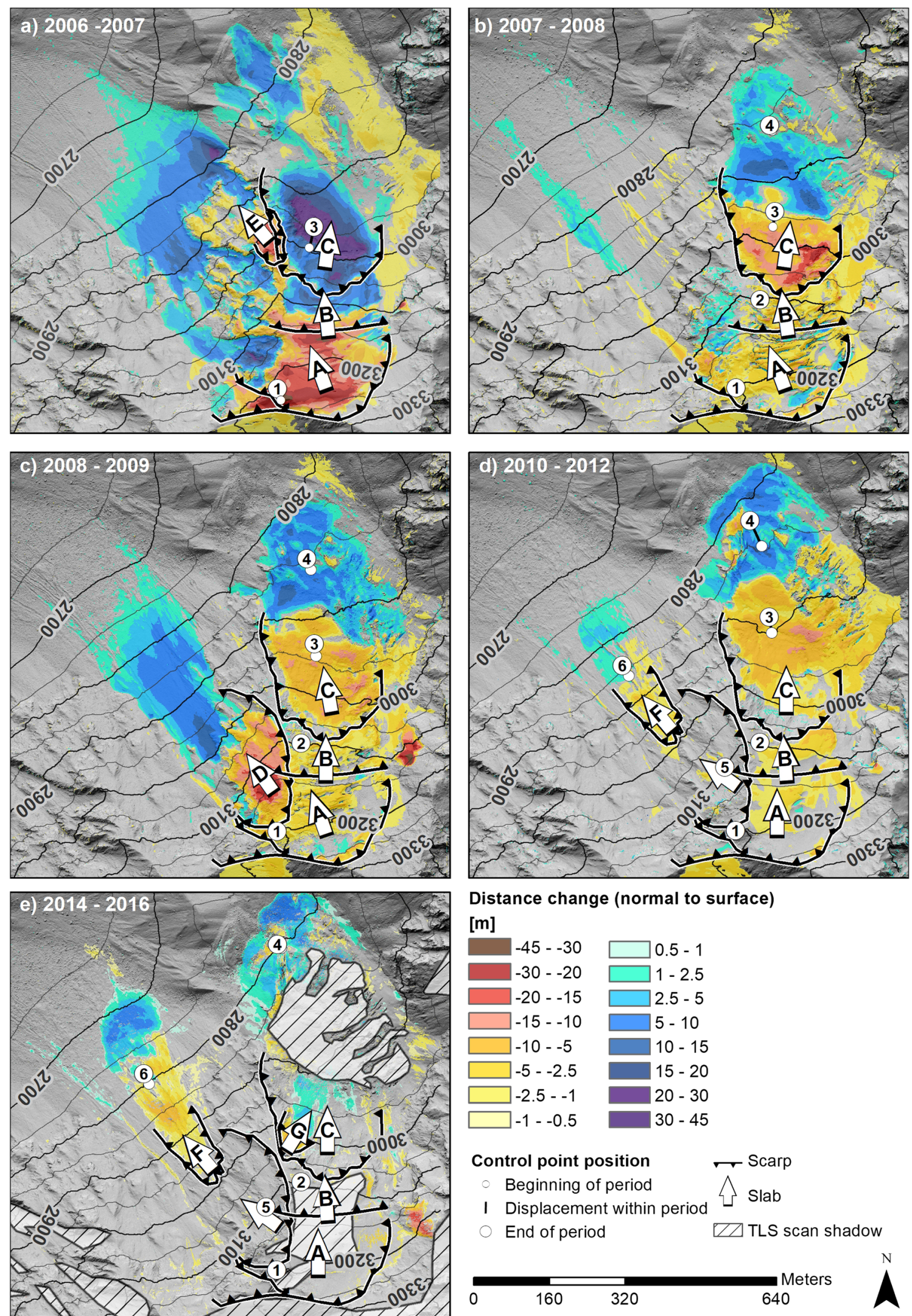

\section{Distance change (normal to surface) \\ [m]

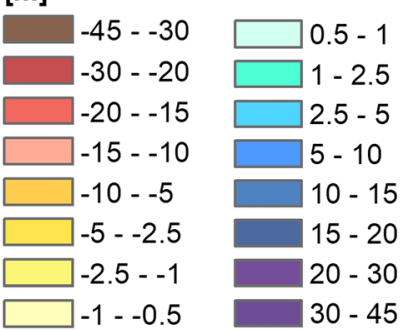

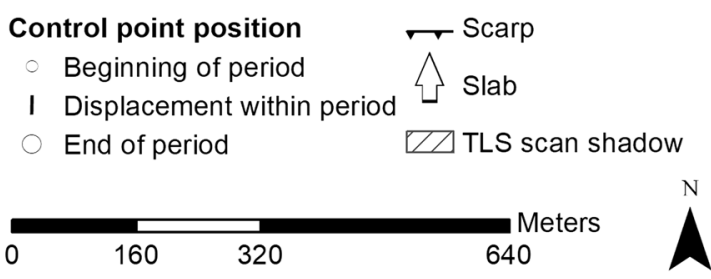

Fig. 7 Distance change maps obtained from multi-temporal ALS and TLS campaigns: a period 2006-07, b period 2007-08, c period 200809, d) period 2010-12, and e) period 2014-16. The control points are

based on displacement analyses and show the location of the point at the beginning and at the end of the respective period 


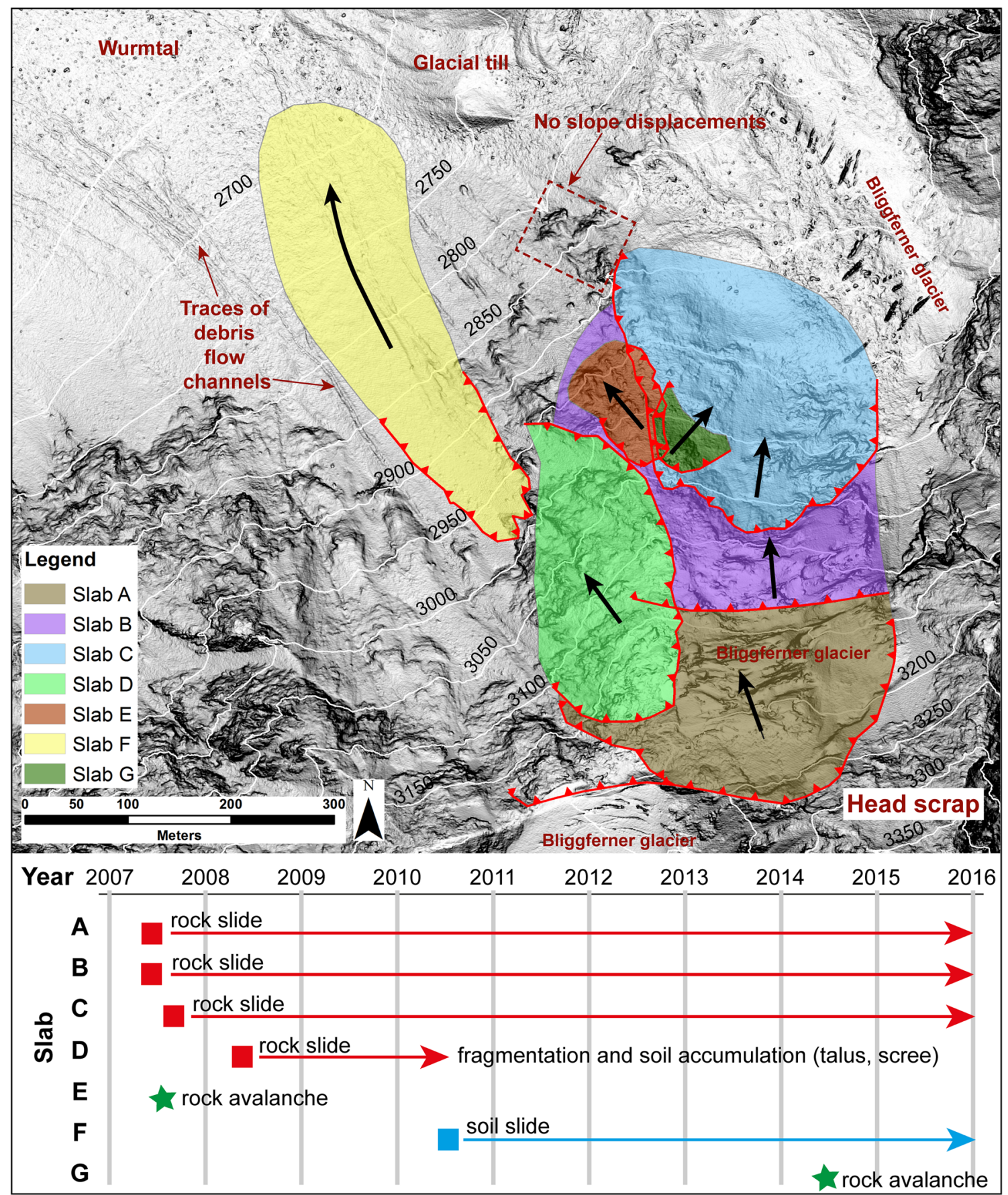

Fig. 8 Summarised illustration of rock slope processes at the Bliggspitze showing location, area, displacement direction, type of failure, time of origin and temporal evolution of slabs

image of 2007 and by time-lapse imagery from the webcam installed for monitoring the Bliggspitze rock slide (Fig. 10). On the ortho-image captured on 22 September 2007, a crack representing an opening below $1 \mathrm{~m}$ can be observed for the first time. Visual analyses of time-lapse from webcam images show an ongoing enlargement of the scarp at the beginning of October 2007. ALS data, captured on 11 October 2007, indicate displacements of the lower slope section, i.e. toe of the rock slide, of about $39 \mathrm{~m}$ towards $\mathrm{N}$. In this section of the slope, a terrain uplift of up to $40 \mathrm{~m}$ was measured, induced by slope displacements and soil accumulations from rock/ice falls and avalanches (Fig. 7a).

In addition to slabs $\mathrm{A}, \mathrm{B}$ and $\mathrm{C}$, a further displaced rock mass evolved at the NW slope around 3050-2930 m a.s.l. (Figs. 7a and 8). There, a new scarp represents the source of slab E which was formed shortly after the initiation of the rock slide during summer 2007. The spatial relationship between the location of the scarp and the area of debris accumulation 


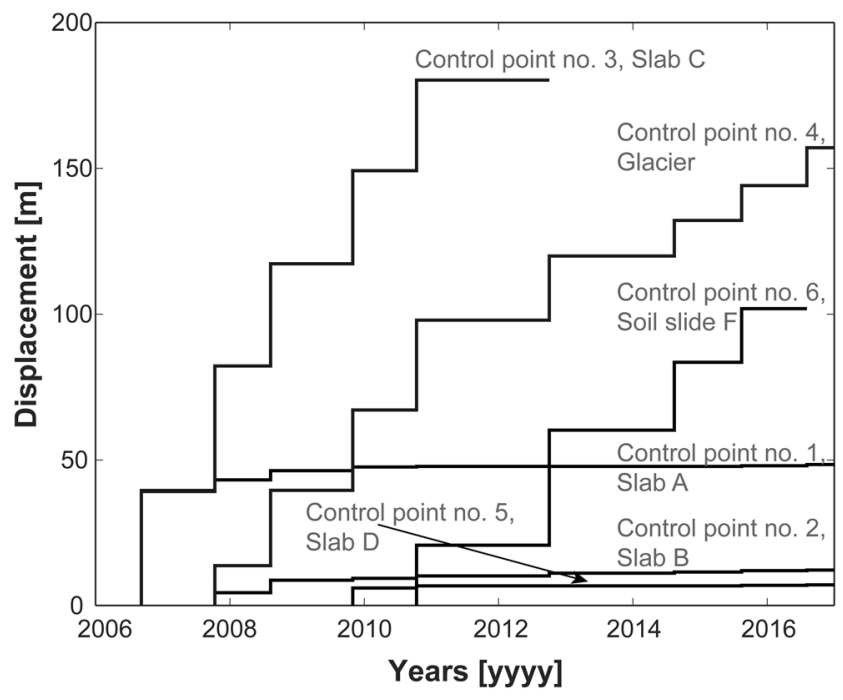

Fig. 9 Stair diagram indicating total displacements of selected surface terrain areas, i.e. control points over time (location of control points is shown in Fig. 7). Starting time depends on the ability to track terrain surface features and does not necessarily have to correlate with the beginning and formation of a rock slide slab

directly below suggest that a rapid slope process, i.e. a rock avalanche, had occurred. Based on the elevation of the upper rim of the scarp (3050 $\mathrm{m}$ a.s.1), the distal-most deposits (2650 $\mathrm{m}$ a.s.l.) and the runout distance of $550 \mathrm{~m}$, a runout travel angle of $36^{\circ}$ was determined. In the scarp area of slab $\mathrm{E}$, a rock mass height loss of up to $22 \mathrm{~m}$ was obtained from distance change analyses, coinciding with a similar amount of debris accumulation at lower slope areas (Fig. 7a). During this time period, ongoing rock/ice fall and debris flow events released from the fractured and disintegrated rock slide slabs A, $\mathrm{B}$, and $\mathrm{C}$, which led to considerable talus depositions of several tens of metres at the foot of the N and NW slope (2740 to $2930 \mathrm{~m}$ a.s.1.).

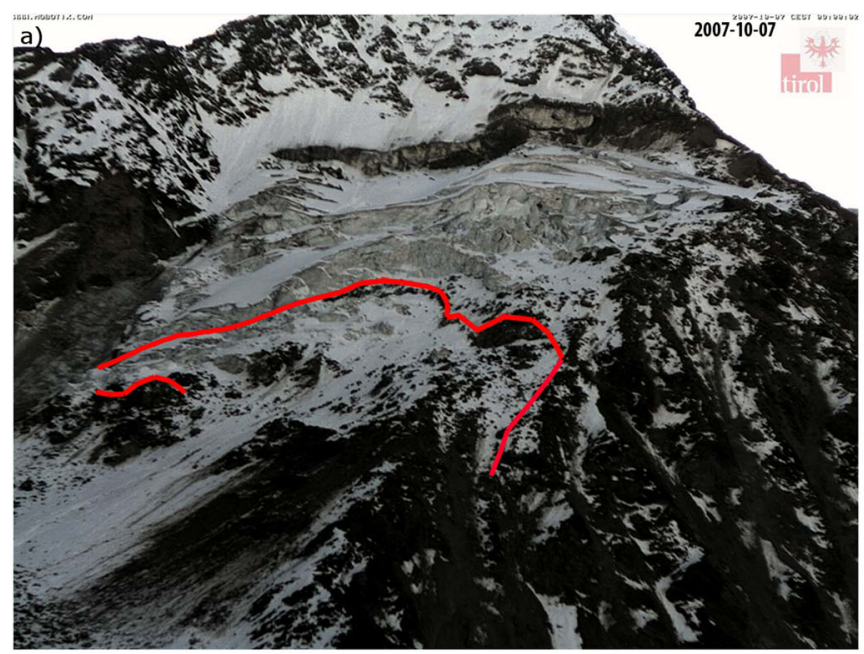

Fig. 10 Webcam-based time-lapse images showing the initial formation of the rock slide slab C: a image taken on 10.10.2007, with the red line tracing the newly formed tension crack, and $\mathbf{b}$ image taken on

\section{Period 2007 to 2008: Ongoing slope displacements}

The period between 2007 and 2008 is characterised by ongoing displacements of the slabs A, B and C (Figs. 7b and 9). The activity of slab A decreased significantly, reaching displacements of $40 \mathrm{~m}$ in summer 2007 to $4 \mathrm{~m}$ between 2007 and 2008. For slab B, a displacement of about $4 \mathrm{~m}$ was determined. At the toe of slab C, displacements of up to $43 \mathrm{~m}$ were measured. The $\mathrm{N}$-directed slope displacements of slab $\mathrm{C}$ caused a lowering of the terrain surface by more than $20 \mathrm{~m}$. From here towards N, the subsurface is covered by the glacier and affected by terrain uplift of up to $15 \mathrm{~m}$ (Fig. 7b).

\section{Period 2008 to 2009: Ongoing displacements, formation of slab $D$}

Generally, during the period 2008-2009, the Bliggspitze rock slide was characterised by decreasing slope displacements of the pre-existing slabs (Fig. 9), but also by the formation of a new slab, termed slab D (Figs. 7c and 8). Field observations, webcam time-lapse images, ALS distance maps and displacement analyses based on image correlation and break line tracking indicate ongoing slope deformations and terrain surface lowering of all three slabs A, B and C (Fig. 7c). A terrain surface lowering of less than $10 \mathrm{~m}$ was observed between the head scarp of slab A and the scarp of slab C. Given that most of this area was covered by the glacier, it remained unclear if the terrain surface lowering was caused by rock slide deformations only or additionally by the degradation of the ice cover. During the period 2008-2009, slab C is characterised by $\mathrm{N}$-directed displacements of about $35 \mathrm{~m}$, inducing a terrain surface lowering of more than $10 \mathrm{~m}$ (Fig. $7 \mathrm{c}$ ).

Considerable slope deformations were also determined at the upper part of the NW-facing slope, which is part of the

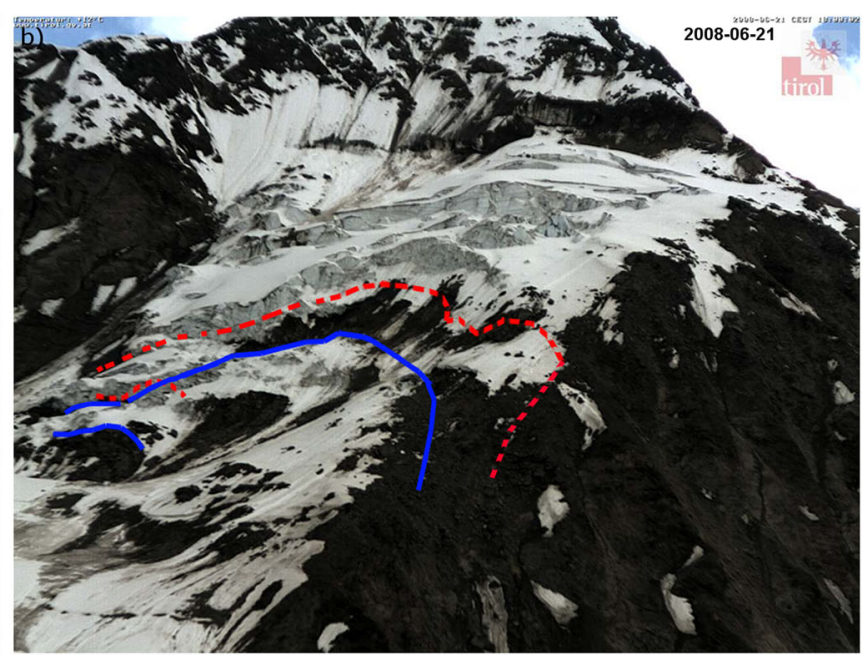

21.06.2008, with the distance between the red dashed line and the blue line indicating the large offset at the scarp since 10.10.2007 (data from Federal State of Tyrol) 
NW-striking trough (Fig. 7c). Early indications of a new slope activity in this area can already be identified in the previous period 2007-2008 (Fig. 7b). At the upper part of the NWfacing slope, a new scarp was formed along the N-S-striking unglaciated ridge, releasing a new slab which is displacing towards NW (slab D, Figs. 7c, 8 and 11a). This new slab was structurally predisposed by the N-dipping foliation and a NW-SE-striking brittle fault zone with related fractures acting as a lateral boundary. In the main scarp area of slab D, distance change analyses show a distinct mass waste with a terrain surface lowering of up to $30 \mathrm{~m}$ (Fig. 7c). This slope process is related to numerous sliding, rock fall and debris flow events. The displaced material accumulated further downslope, causing soil accumulation of up to $10 \mathrm{~m}$ thickness.

\section{Period 2010 to 2012: Ongoing displacements, initial formation of the soil slide $F$}

Period 2010-2012 was characterised by ongoing slope deformations, primarily by large displacements of slab $\mathrm{C}$ with around $31 \mathrm{~m}$ at the slope toe (Fig. 9). At some locations, slope displacements caused terrain surface lowering of up to $15 \mathrm{~m}$ and terrain uplift of about $10 \mathrm{~m}$ (Figs. 7d and 8). Slab A and slab B were further affected by N-directed displacements, but at a much lower activity, i.e. displacement rates are between 0.2 and $0.4 \mathrm{~m} / \mathrm{a}$. Little activity of $0.15 \mathrm{~m} / \mathrm{a}$ was also determined by ALS image correlation for slab D. Since the initial development of the Bliggspitze rock slide and during this period, material from other sections of the NW slope and scarp area of slab D were released and accumulated as talus deposits further down. The ongoing debris deposition led to a progressive steepening of the slope until limit-equilibrium condition was reached, and a new soil slide was formed with a scarp at and below $3000 \mathrm{~m}$ a.s.l. (soil slide F, Figs. 7d and 11b). From the scarp to the toe, the soil slide is characterised by a length of approx. $450 \mathrm{~m}$ and a maximum width of $130 \mathrm{~m}$, respectively. ALS-based distance change analyses indicate that the scrap area was affected by a terrain surface lowering of about $3 \mathrm{~m}$. At the toe, material accumulation of $3 \mathrm{~m}$ represented by terrain surface uplift was measured (Fig. 7d). The average slope angles are approx. $38^{\circ}$ in the scarp and $35^{\circ}$ in the toe area. Between 2010 and 2012, displacements of about $20 \mathrm{~m}$ were measured at the central part of the soil slide.

\section{Period 2014 and 2016: Ongoing displacements, formation of slab G}

The deformation characteristics of this period were obtained from TLS measurements performed at the foot of the slope. Displacement analyses, i.e. image correlation and break-line tracking on terrain surfaces outside of the scan shadow, show a minor slope activity of slab A and B of about $0.2 \mathrm{~m} / \mathrm{a}$. At the left flank of slab $\mathrm{C}$, a new detachment area was detected, characterised by the shape of a scarp and a terrain surface lowering of up to $10 \mathrm{~m}$ (Figs. 7e and 8). This scarp indicates the source of a new event (i.e. slab G), and is approx. $50 \mathrm{~m}$ high and $70 \mathrm{~m}$ wide, respectively. The scarp area of slab $\mathrm{G}$ is located directly above a distinct accumulation area, which in turn is approx. $110 \mathrm{~m}$ long and $80 \mathrm{~m}$ wide and is showing up to $3 \mathrm{~m}$ of debris accumulation (Fig. 7e). The spatial relationship between the location of the scarp and the deposition area on

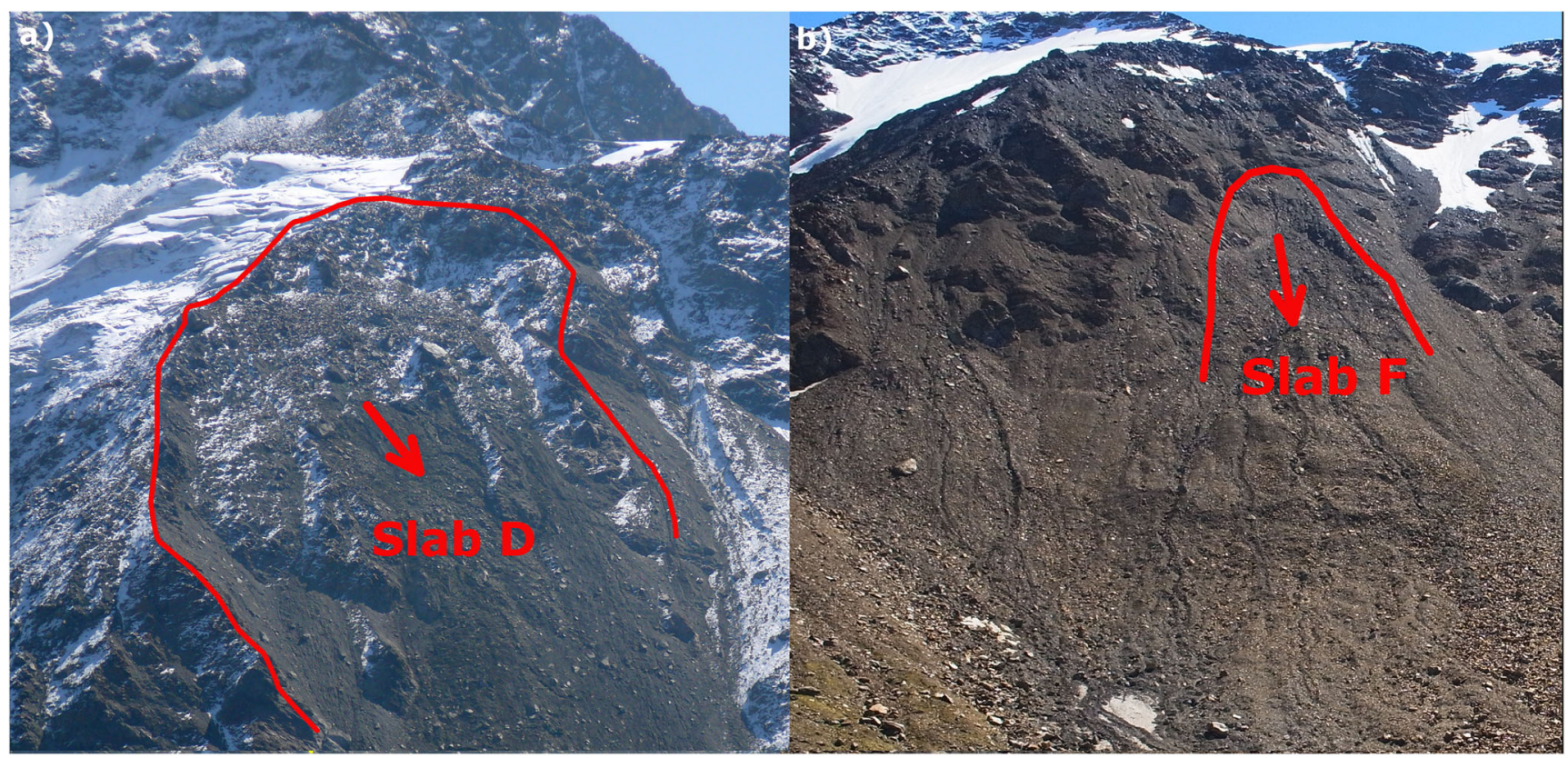

Fig. 11 Field images taken form N: a scarp (red line) and geometry of rock slide slab D on 09.07.2009, and b situation of the soil slide F on 28.09.2014 
the glacier below indicates the evolution of slab G, which represents a rock avalanche. The most conspicuous area of slope activity during the period 2014-2016 is related to the soil slide F, which is still moving towards NW (Fig. 7e). The scarp area further extended and the toe of the slide moved more than $100 \mathrm{~m}$ towards NW. These large displacements led to a reduction of the average slope angle at the toe from $35^{\circ}$ at the previous period to approx. $29^{\circ}$. At the toe, the thickness of the soil slide increased to a maximum of $8 \mathrm{~m}$. The shape of the soil slide surface is lobate and tongue-like, where an enlargement of the mass from $120 \mathrm{~m}$ to $150 \mathrm{~m}$ along the displacement path has occurred. The soil slide shows an average displacement rate of about $20 \mathrm{~m} / \mathrm{a}$.

\section{Geological-geometrical rock slide model}

A synopsis and compilation of the Bliggspitze rock slide comprising location, area and scarps of individual rock slide slabs, slab displacement directions, landslide type of each slab and temporal evolution is shown in Fig. 8. There and before it can be clearly observed that the Bliggspitze rock slide represents a temporally changing complex geometrical 3D system, where rock slide slabs were newly formed at different times and slid downwards as slides, failed as rock falls and avalanches or dispersed to soil which accumulated as talus deposits further down. Thus, a geological-geometrical rock slide model representing the slope situation from 2010, i.e. where the slope activity is significantly reduced, is depicted in a longitudinal N-S section (Fig. 12). This 2D model represents the large-scale rock slide slabs A, B and C, which are characterised by $\mathrm{N}$-directed displacements, and the smaller slab D with a movement directed towards NW (i.e. displacement obliquely to the longitudinal $\mathrm{N}-\mathrm{S}$ section). Considering field surveys, webcam images, ALS/TLS data and ortho-images, slabs A, B, C and D have displaced individually several tens of metres, and therefore we suppose that continuous shear zones/slip surfaces were generated for each of the slabs. In addition, we infer the existence of a main basal shear zone extending from the head scarp (dip angle between 36 to $53^{\circ}$ ), and here following the major $\mathrm{N}$-dipping fault plane (i.e. mean fault orientation 348/44), to the lower part of the slope at about $2900 \mathrm{~m}$ a.s.l. Based on detailed analyses of multi-temporal ALS and high-resolution TLS measurements, we observed no slope displacements (i.e. within the accuracy of 10 years of monitoring) on the NW-striking rock ridge outcropping below $2900 \mathrm{~m}$ a.s.l. (Figs. 2a and 8, Fey et al. 2015). Thus, we conclude that the main basal shear zone outcrops between 2900 and $2950 \mathrm{~m}$ a.s.l. (Figs. 8 and 12). However, since slab $\mathrm{C}$ has slid over the outcropping trace of the main basal shear zone, the trace is covered by rock/soil and thus hardly visible. According to the geometrical model and the dip angles of the displacement vectors (see Fig. 12), the basal shear zone is probably curved and reduces the inclination from about $44^{\circ}$ at the head scarp to about $17^{\circ}$ at the toe (i.e. rotational slide). Geological field data and remote sensing data suggest a compression of the glacier at the slope foot due to the N-directed displacements of slab C. Large displacements and uplift of the glacier were observed during field campaigns and were measured by ALS (Fig. 7).

The Bliggspitze rock slide comprises a maximum thickness of approx. $65 \mathrm{~m}$, a length in the $\mathrm{N}-\mathrm{S}$ direction of more than $530 \mathrm{~m}$ and a width of approx. $300 \mathrm{~m}$ (Fig. 3). A volume determination based on the DEM from 2006 and the reconstruction of the topography without the rock slide mass (i.e. topography of the basal shear zone) show a total volume in the range between 3.9 to 4.3 million $\mathrm{m}^{3}$. The large-scale slabs, i.e. $\mathrm{A}, \mathrm{B}, \mathrm{C}$ and $\mathrm{D}$, comprise volumes in the range from several hundreds of thousands to several millions of $\mathrm{m}^{3}$. The extremely rapid rock avalanches originating from the scarps $E$ and $G$ are much smaller and show volumes of approx. 70,000 and $15,000 \mathrm{~m}^{3}$, respectively. The slowly moving soil slide F comprises a volume of approx. $100,000 \mathrm{~m}^{3}$. The intensive fracturing of the rock slide mass during the sliding process, and thus the associated long-term activity of rock falls, rock avalanches, debris flows and rock slides, caused considerable mass waste characterised by the deposition of loose soil at lower elevations. A comparison of DEMs measured before and after the development of the Bliggspitze rock slide reveals a mass loss of more than 0.9 million $\mathrm{m}^{3}$ from the rock slide area. In contrast, the deposition area outside of the slide boundary, i.e. mostly below the basal shear zone, comprises a volume increase by approx. 1.3 million $\mathrm{m}^{3}$. Given that the rock slide is composed of both fractured rock mass and glacial ice, the DEM-based GIS calculations cannot distinguish between those two features.

\section{Discussion}

For prognoses of the slope deformation behaviour and hazard assessments, it is crucial to assess, if a fully persistent basal shear zone has been formed and which geometry and volume is resulting from the initial rock slide failure process. The volume of a rock slide, when collapsing rapidly, affects the runout length, as shown by several compiled data and empirical relationships obtained thereof (e.g. Heim 1932; Scheidegger 1973; Körner 1976; Okura et al. 2000; Legros 2002; Prager 2010).

In contrast to major single events, the Bliggspitze rock slide shows a spatially and temporally complex failure and deformation process characterised by the sequential development and movement of individual rock slide slabs. The rock slide slabs were formed laterally or vertically (on top of each other) adjacent, and when active were displaced at different velocities (Fig. 8). For most of the rock slide slabs, especially for the 


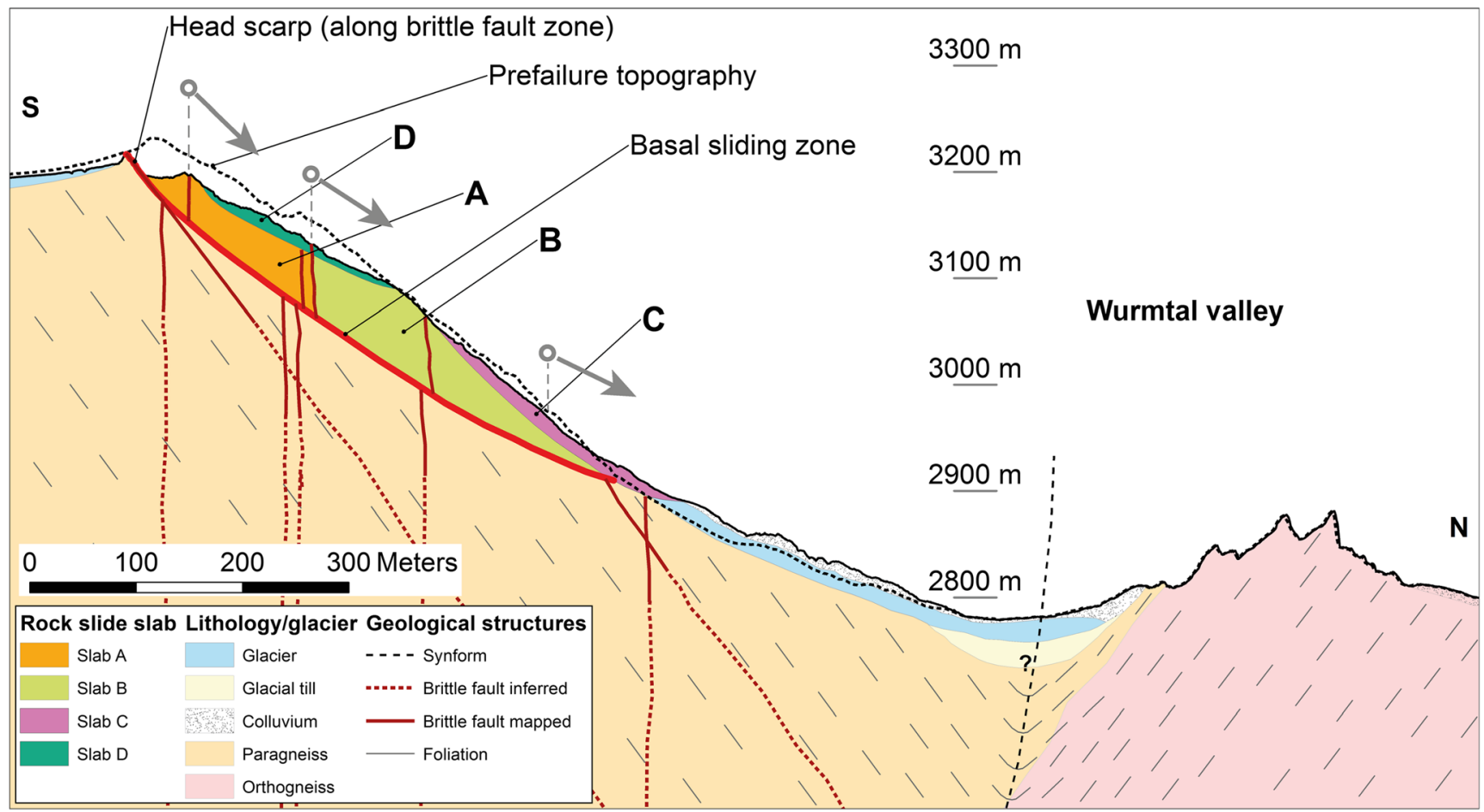

Fig. $12 \mathrm{~N}-\mathrm{S}$-directed geological section showing the pre-failure topography, topography from 2010 , offset at the head scarp, rock slide slabs A, B, C and D, the basal shear zone, displacement vectors of slabs
$\mathrm{A}, \mathrm{B}$ and $\mathrm{C}$, interaction with the glacier at the foot, main foliation, axial plane of the synform, and brittle fault zones (for location, see Fig. 3) larger one, displacements of several tens of metres were measured, but for these slabs, no accelerations with total collapse were observed. However, a few smaller rock slide slabs featuring volumes of up to several $10,000 \mathrm{~m}^{3}$ failed extremely rapid and formed rock/ice avalanches and rock falls.

Concerning the existence of a basal shear zone, geotechnical subsurface investigations (drillings, inclinometer monitoring) have not been performed in view of the remote (inaccessible) and hazardous terrain and the high costs. Thus, the assessment of a potential basal sliding zone is based solely on geological field surveys and surface ALS/TLS deformation measurements. In order to gain additional indications as to whether a basal shear zone has been formed, a simple conceptual geometrical approach is applied and compared with other case studies in metamorphic rocks. This approach considers (i) the maximum shear offset at the head scarp and (ii) the maximum length of the basal shear zone obtained as the inferred length of the rock slide in direction of movement. For many rock slides, the maximum shear offset at the head scarp is well defined and obviously indicates discrete shear displacement along a rather planar failure surface resulting from rock mass strain localisation. The lengths of the basal shear zone can be inferred from geological field surveys, deformation data and terrain models, and under ideal conditions, the rock slide boundary is laterally exposed and traceable along the right and/or left flanks. Considering the shear offset at the head scarp, $\Delta \mathrm{s}$, and the inferred total length of the basal shear zone from the scarp to the toe of the slope, $l_{\mathrm{bs}}$, a ratio defined as $R_{\mathrm{s}}=\Delta \mathrm{s} / \mathrm{l}_{\mathrm{bs}}$ can be determined. This approach is based on the assumption that a sufficiently large shear offset at the head scarp and below is required to develop a fully persistent basal shear zone due to progressive failure processes and strain localisation (Eberhardt et al. 2004; Riva et al. 2018). However, the length of the needed discrete shear offset is depending on the size of the rock slide, and therefore we defined the ratio $R_{s}$. Given that the approach is purely empirical, very simple and thus neglects site-specific rock mass properties, we compared the Bliggspitze rock slide with well-investigated cases studies in similar rock masses showing an analogical failure behaviour. At the Bliggspitze rock slide, a clearly mappable head scarp comprising a discrete shear offset of $\Delta \mathrm{s}=40 \mathrm{~m}$ was developed. Based on ALS/TLS data and episodically occurring springs and wetting zones, only the left lateral trace of the inferred basal shear zone was at least partly traceable. The right lateral trace was covered by the glacier and thus not exposed and traceable. Considering the geological-geometrical rock slide model (Fig. 12), a maximum length for the basal shear zone of $l_{b s}=560 \mathrm{~m}$ was gained. Based on these two parameters, a slope ratio $R_{s}=$ $0.071 \mathrm{~m} / \mathrm{m}$ was determined. Comparable rock slides in similar rock types, i.e. schists and paragneisses with a basal shear zone identified by mapping, geophysical investigations and drillings, are characterised by $R_{s}$ values between 0.033 and $0.181 \mathrm{~m} / \mathrm{m}$ (Fig. 13; Zangerl et al. 2010; Zangerl and Prager 


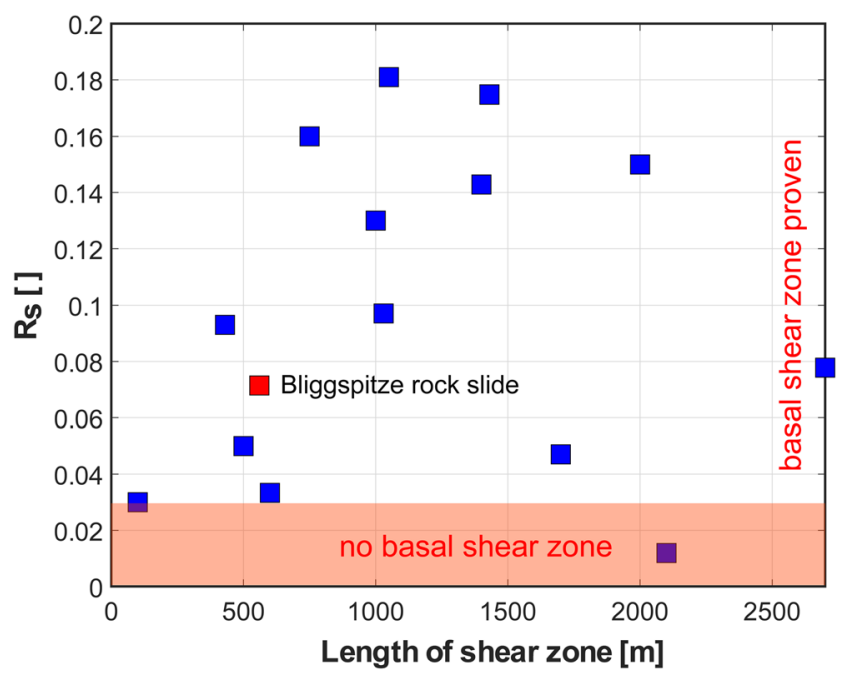

Fig. 13 Compilation and determination of $\mathrm{R}_{\mathrm{s}}$ values for different case studies located in similar rock types. Values at and below $R_{s}=0.3 \mathrm{~m} / \mathrm{m}$ are representing case studies where a basal shear could not be determined in the field

2008). Case studies with high $R_{\mathrm{s}}$ values ( $>0.130$ ) are typically those with head scarp offsets in the range of 100 to $300 \mathrm{~m}$ and thus representing a very advanced stage of slope deformation. The value of $R_{s}=0.071 \mathrm{~m} / \mathrm{m}$ confirms conclusions gained from field observations and deformation measurements at the Bliggspitze rock slide that a fully persistent basal shear zone is likely to be encountered. The application of this conceptual approach may be limited if the pre-existing discontinuity network favours slope processes characterised by deepseated flexural toppling causing large surface displacements without any basal shear zone. (e.g. Zischinsky 1966, 1969; Reitner and Linner 2009). In such cases, the rock mass can accumulate much larger displacements before strain localisation occurs and a shear zone is formed. Furthermore, the proposed empirical approach requires considerably more data from other case studies in similar rock to define the boundary between both fields in Fig. 13 more precisely.

The impact of permafrost degradation on the evolution of the Bliggspitze rock slide is only poorly understood. Nevertheless, clear indications for the existence of permafrost were found either by visual inspection of ice-filled fractures at the head scarp or by applying the BTS method. From literature, it is known that the presence of ice-bonded discontinuities generally increases slope stability. For example, Davies et al. (2001) showed by direct shear tests in laboratory that the shear strength of ice is usually higher at lower temperatures and decreases under warming conditions. Thus, ice-filled fractures would increase the overall rock mass strength and would reduce sub-critical crack growth (Atkinson 1989), i.e. a process which is required for coalescence (linkage) of the fracture network and the generation of a continuous basal shear zone. Furthermore, Krautblatter et al. (2013) proposed a timedependent rock-ice mechanical model for ice-filled fractures, which considers (i) secondary creep of ice, (ii) failure of rockice contacts, (iii) friction of rock-rock contacts of discontinuities, and (iv) fracturing of intact rock bridges. Concerning this model, ice-fillings of fractures can act as a nonlinear viscous material, whereby the shear strain rate increases by an order of a magnitude when the temperature rises from -10 to $0{ }^{\circ} \mathrm{C}$. Furthermore, laboratory tests indicate that failure of rock-ice contacts is favoured by warming, i.e. temperature around $0{ }^{\circ} \mathrm{C}$ and above, rather than low freezing temperatures. For warming permafrost rocks close to thawing, Krautblatter et al. (2013) suppose that (i) ice-mechanical processes are dominating rock slope failures at shallow depths (less than $20 \mathrm{~m}$ ), and (ii) rock-mechanical processes are more relevant for deep-seated rock slope failures. Additional laboratory tests focusing on water-saturated intact rock samples showed a reduction of the compressive and tensile strength by rock temperatures increasing from low freezing temperatures up to $0{ }^{\circ} \mathrm{C}$ (Kodama et al. 2013). Further mechanisms related to permafrost such as ice segregation may cause growth of continuous ice-filled cracks which in turn may trigger fracture widening and thus progressive rock mass loosening. Subsequent thawing conditions (e.g. freeze-thaw cycles in warming permafrost and periglacial environments) can substantially affect the rock mass strength. Taking these factors into account, an impact of permafrost on the Bliggspitze rock slide is likely. According to literature data above, we assume that permafrost degradation is more relevant for near-surface slope destabilisation processes (i.e. active layer) than at greater depths of some decametres where the basal rockslide shear zone is located.

Generally, it is widely accepted that glaciation and deglaciation have an important impact on slope stability of large valley flanks in the Alps. However, it is controversially discussed which processes or combinations/interactions of processes lead to slope failure and particularly which timedependent rock strength weakening mechanisms are relevant. On the one hand, after LGM, long lag times of thousands of years are observed between deglaciation and large-scale slope instabilities (e.g. Prager et al. 2008; Ballantyne et al. 2014). Such large time delays between glacial retreat and slope failures are driven by progressive rock mass failure processes and thus cannot be modelled by simple time-independent geomechanical models (Riva et al. 2018). On the other hand, numerous case studies clearly show a temporal relationship with much shorter lag times (much less than decades) between glacial retreat and the evolution of rock slides (McColl and Davies 2013; Kos et al. 2016; Fey et al. 2017b). Although a much shorter time delay exists, progressive failure processes accompanied by strain localisation are also here essential to form a fully persistent failure surface. Glacial retreat induces in rock slopes complex coupled mechanical, hydrogeological and thermal processes, including stress changes and weight relief, loss of rock mass strength, rock mass fracturing and 
weathering, temperature changes and permafrost degradation, and modifications of the groundwater flow (Grämiger et al. 2017).

At the Bliggspitze rock slide, we assume a major impact on slope stability from glacial retreat during recent decades. As a mechanism, we infer that glacial unloading due to ice weight reduction rather than debuttressing, which typically occurs on slopes interacting with a large valley glacier, are relevant (Ballantyne 2002). Glacial unloading taking place predominately at lower parts of the slide may trigger force imbalances, which in turn cause slope deformations and the growth and linkage of fractures until a fully persistent shear zone is formed. GIS-based volume analyses indicate a total loss of glacial ice atop the rock slide of more than 1.5 million $\mathrm{m}^{3}$ between 1946 and 2006. Depending on this ice volume, more than 1 million $\mathrm{m}^{3}$ melted at the lower part and near the foot of the rock slide. Considering an average glacier ice density of $900 \mathrm{~kg} / \mathrm{m}^{3}$, an ice mass reduction of 900 million $\mathrm{kg}$ resulted (Huss 2013). If the ice mass reduction is related to the total rock slide volume ranging from 3.9 to 4.3 million $\mathrm{m}^{3}$ and the rock mass density of $2300 \mathrm{~kg} / \mathrm{m}^{3}$ (due to rock mass fracturing and loosening $10 \%$ porosity was assumed), a total mass reduction at the foot of the slide between 9 and $10 \%$ was obtained. The unloading of the rock slide due to the glacial retreat is remarkable and may have influenced slope stability, especially because the basal shear zone is curved and a rotational sliding mechanism is determined. Although not quantified so far by comprehensive numerical modelling in this study, it is presumed that the glacial retreat has a major impact on the overall in situ stress state of the slope, and thus may have influenced the failure and formation process of the Bliggspitze rock slide. In order to study and quantify these factors in greater detail, and additional potential trigger and stabilisation factors, coupled 2D/3D numerical modelling will be applied in the framework of subsequent research. On the basis of the findings and models from this study, numerical modelling will be focussing on the impact of (i) glacier unloading during recent decades, (ii) mass waste due to slope processes, and (iii) permafrost degradation on the initial failure process and the future stability evolution.

\section{Conclusion}

The Bliggspitze rock slide acted as a challenging site to test and validate different remote sensing techniques, i.e. ALS, TLS, ortho-images and time-lapse of webcam images in remote and inaccessible terrain influenced by permafrost and glacial retreat. Experience has demonstrated that ALS/TLS data from different campaigns are useful to obtain spatially and temporally variable slope deformation data. Such surface deformation maps, analysed and assessed by geological field surveys, enabled the detection and monitoring of different rock/soil slide slabs and the development of a geometricalkinematical rock slide model. During the initial development stage and the long-term deformation history of the rock slide, three different slab types characterised by different volumes and deformation characteristics were determined. Firstly, large-scale slabs composed of fractured rock mass which are moving at low to moderate velocities were observed (i.e. slabs A, B, C and D). These slabs did not accelerate exponentially or even fail extremely rapidly, but rather reduced the displacement rates after some time (rock slab stabilisation mechanism). Secondly, small-scale slabs composed of fractured rock mass were identified showing continuous acceleration and slope failure as rock falls and rock avalanches (slabs E and G). Thirdly, a slowly-moving soil slide originating from a newly produced talus accumulation area at the foot of the slope (soil slide F) was recognised. Furthermore, long-term observations at the Bliggspitze rock slide demonstrate a complex and still ongoing loss of rock/soil of the slide mass through rock falls, rock avalanches, rock slides and debris flows, and the accumulation of the material at lower heights.

Acknowledgements Open access funding provided by the University of Natural Resources and Life Sciences Vienna (BOKU). The authors wish to acknowledge and thank the TIWAG and the Federal State of Tyrol for providing remote sensing and monitoring data and supporting this research project. We would also like to thank Ass. Prof. Karl Krainer for supporting us with the BTS measurements in the field. This study was part of several alpS landslide projects, which were supported by TIWAG, ILF Consulting Engineers, geo.zt, and the Austrian Research Promotion Agency. The alpS K1-Centre was supported by the Federal Ministries BMVIT and BMWFW and by the States of Tyrol and Vorarlberg in the framework of "COMET - Competence Centres for Excellent Technologies". COMET was funded and administrated by FFG.

Open Access This article is distributed under the terms of the Creative Commons Attribution 4.0 International License (http:// creativecommons.org/licenses/by/4.0/), which permits unrestricted use, distribution, and reproduction in any medium, provided you give appropriate credit to the original author(s) and the source, provide a link to the Creative Commons license, and indicate if changes were made.

\section{References}

Abellán A, Oppikofer T, Jaboyedoff M, Rosser NJ, Lim M, Lato MJ (2014) Terrestrial laser scanning of rock slope instabilities. Earth Surf. Process. Landforms 39:80-97. https://doi.org/10.1002/esp. 3493

Atkinson BK (1989) Fracture mechanics of rock. Elsevier Science, Burlington, p 548

Ballantyne CK (2002) Paraglacial geomorphology. Quat Sci Rev 21: 1935-2017. https://doi.org/10.1016/S0277-3791(02)00005-7

Ballantyne CK, Sandeman GF, Stone JO, Wilson P (2014) Rock-slope failure following Late Pleistocene deglaciation on tectonically stable mountainous terrain. Quat Sci Rev 86:144-157. https://doi.org/10. 1016/j.quascirev.2013.12.021

Bortenschlager S (1984) Beitrage zur Vegetationsgeschichte Tirols I. Inneres Ötztal und unteres Inntal, Berichte Naturwiss-Mediz Vereins Innsbruck 71:19-56 
Cossart E, Braucher R, Fort M, Bourlès DL, Carcaillet J (2008) Slope instability in relation to glacial debuttressing in alpine areas (upper durance catchment, southeastern France): evidence from field data and $10 \mathrm{Be}$ cosmic ray exposure ages. Geomorphology 95:3-26. https://doi.org/10.1016/j.geomorph.2006.12.022

Crosta GB, Di Prisco C, Frattini P, Frigerio G, Castellanza R, Agliardi F (2014) Chasing a complete understanding of the triggering mechanisms of a large rapidly evolving rockslide. Landslides 11:747-764. https://doi.org/10.1007/s10346-013-0433-1

Davies MCR, Hamza O, Harris C (2001) The effect of rise in mean annual temperature on the stability of rock slopes containing icefilled discontinuities. Permafrost Periglac Process 12:137-144. https://doi.org/10.1002/ppp.378

Dejean de la Bâtie J (2016) Ingenieurgeologische und hydrogeologische Untersuchung der Massenbewegung im Bereich der Bliggspitze im Ötztal-Stubai-Kristallin (Kaunertal, Tirol). University of Innsbruck, Faculty of Geo- and Atmospheric Sciences, Innsbruck, Master Thesis $159 \mathrm{pp}$

Delacourt C, Allemand P, Berthier E, Raucoules D, Casson B, Grandjean P, Pambrun C, Varel E (2007) Remote-sensing techniques for analysing landslide kinematics: a review. Bull Soc Geol Fr 178: 89-100. https://doi.org/10.2113/gssgfbull.178.2.89

Deline P, Gruber S, Delaloye R, Fischer L, Geertsema M, Giardino M, Hasler A, Kirkbride M, Krautblatter M, Magnin F, McColl S, Ravanel L, Schoeneich P (2015) Ice loss and slope stability in High-Mountain regions. In: Snow and ice-related hazards, risks and disasters. Elsevier, pp 521-561

Dewez TBJ, Girardeau-Montaut D, Allanic C, Rohmer J (2016) Facets: a cloud compare plugin to extract geological planes from unstructured $3 \mathrm{~d}$ point clouds. Int Arch Photogramm Remote Sens Spatial Inf Sci XLI-B5:799-804. https://doi.org/10.5194/isprsarchives-XLI-B5799-2016

Eberhardt E, Stead D, Coggan JS (2004) Numerical analysis of initiation and progressive failure in natural rock slopes-the 1991 Randa rockslide. Int J Rock Mech Min Sci 41:69-87

Evans SG, Clague JJ (1994) Recent climatic change and catastrophic geomorphic processes in mountain environments. Geomorphology 10:107-128. https://doi.org/10.1016/0169-555X(94)90011-6

Fey C (2018) Remote sensing applications for deformation monitoring of landslides in alpine environment Doctoral thesis, $152 \mathrm{pp}$.

Fey C, Wichmann V (2017) Long-range terrestrial laser scanning for geomorphological change detection in alpine terrain - handling uncertainties. Earth Surf. Process. Landforms 789-802. https://doi.org/ 10.1002/esp.4022

Fey C, Rutzinger M, Wichmann V, Prager C, Bremer M, Zangerl C (2015) Deriving 3D displacement vectors from multi-temporal airborne laser scanning data for landslide activity analyses. GISci Remote Sens 52:437-461. https://doi.org/10.1080/15481603.2015. 1045278

Fey C, Wichmann V, Rett H, Perzlmaier S (2017a) Multi-temporal longrange laser scanning for spatial deformation monitoring of alpine slopes. In: Hanke K, Weinold T (eds) 19. Internationale geodätische Woche Obergurgl 2017, 1.Neuerscheinung. Wichmann, H; Wichmann Verlag, Berlin, pp. 247-252

Fey C, Wichmann V, Zangerl C (2017b) Reconstructing the evolution of a deep-seated rockslide (Marzell) and its response to glacial retreat based on historic and remote sensing data. Geomorphology 298: 72-85. https://doi.org/10.1016/j.geomorph.2017.09.025

Fischer L, Purves RS, Huggel C, Noetzli J, Haeberli W (2012) On the influence of topographic, geological and cryospheric factors on rock avalanches and rockfalls in high-mountain areas. Nat Hazards Earth Syst Sci 12:241-254. https://doi.org/10.5194/nhess-12-241-2012

Fischer A, Seiser B, Stocker Waldhuber M, Mitterer C, Abermann J (2015) Tracing glacier changes in Austria from the little ice age to the present using a lidar-based high-resolution glacier inventory in
Austria. Cryosphere 9:753-766. https://doi.org/10.5194/tc-9-7532015

Gischig VS (2011) Kinematics and failure mechanisms of the Randa rock slope instability (Switzerland). Doctoral thesis, Nr. 19730, ETH, Zürich, 204 pp.

Glira P, Pfeifer N, Briese C, Ressl C (2015) A correspondence framework for ALS strip adjustments based on variants of the ICP algorithm. Photogrammetrie - Fernerkundung - Geoinformation 2015(4):275289

Grämiger LM, Moore JR, Gischig VS, Ivy-Ochs S, Loew S (2017) Beyond debuttressing: mechanics of paraglacial rock slope damage during repeat glacial cycles. J Geophys Res Earth Surf 322:243. https://doi.org/10.1002/2016JF003967

Haeberli W (1973) Die Basis-Temperatur der winterlichen Schneedecke als möglicher Indikator für die Verbreitung von Permafrost in den Alpen. Z Gletscherk Glazialgeol 9:221-227

Hammer W (1922) Geologischer Führer durch die Westtiroler Zentralalpen, Sam. geol. Führer XXII. Gebrüder Bornträger, Wien, $168 \mathrm{pp}$.

Heim A (1932) Bergsturz und Menschenleben. Beiblatt zur Vierteljahrsschrift der Naturforschenden Gesellschaft in Zürich. Fretz \& Wasmuth, 218 pp.

Hoelzle M (1992) Permafrost occurrence from BTS measurements and climatic parameters in the eastern Swiss Alps. Permafrost Periglac Process 3:143-147. https://doi.org/10.1002/ppp.3430030212

Huggel C (2009) Recent extreme slope failures in glacial environments: effects of thermal perturbation. Quat Sci Rev 28:1119-1130. https:// doi.org/10.1016/j.quascirev.2008.06.007

Hungr O, Leroueil S, Picarelli L (2014) The Varnes classification of landslide types, an update. Landslides 11:167-194. https://doi.org/ 10.1007/s10346-013-0436-y

Huss M (2013) Density assumptions for converting geodetic glacier volume change to mass change. Cryosphere 7:877-887. https://doi.org/ $10.5194 /$ tc-7-877-2013

Ivy-Ochs S, Kerschner H, Maisch M, Christl M, Kubik PW, Schlüchter C (2009) Latest Pleistocene and Holocene glacier variations in the European Alps. Quat Sci Rev 28:2137-2149

Jaboyedoff M, Couture R, Locat P (2009) Structural analysis of Turtle Mountain (Alberta) using digital elevation model: toward a progressive failure. Geomorphology 103:5-16. https://doi.org/10.1016/j. geomorph.2008.04.012

Kerschner H (1979) Spätglaziale Gletscherstände im inneren Kaunertal (Ötztaler Alpen). Innsbrucker Geograph Studien (Leidlmair Festschrift II) 6:235-247

Kerschner H, Nicolussi K (2014) Lateglacial and Holocene advance record of the Gepatschferner, Kaunertal, Tyrol. In: Kerschner H, Krainer K, Spötl C (eds) From the foreland to the Central Alps: field trips to selected sites of quaternary research in the Tyrolean and Bavarian Alps. Geozon, Berlin, pp 144-151

Keuschnig M (2016) Long term monitoring of permafrost affected rock walls. Technische Universität München, Ingenieurfakultät Bau Geo Umwelt, München, $117 \mathrm{pp}$.

Kodama J, Goto T, Fujii Y, Hagan P (2013) The effects of water content, temperature and loading rate on strength and failure process of frozen rocks. Int J Rock Mech Min Sci 62:1-13. https://doi.org/10. 1016/j.ijrmms.2013.03.006

Körner HJ (1976) Reichweite und Geschwindigkeit von Bergstürzen und Fließschneelawinen. Rock Mech 8:225-256. https://doi.org/10. 1007/BF01259363

Kos A, Amann F, Strozzi T, Delaloye R, von Ruette J, Springman S (2016) Contemporary glacier retreat triggers a rapid landslide response, great Aletsch glacier, Switzerland. Geophys Res Lett 43: 12,466-12,474. https://doi.org/10.1002/2016GL071708

Krautblatter M, Funk D, Günzel FK (2013) Why permafrost rocks become unstable: a rock-ice-mechanical model in time and space. 
Earth Surf Proc Landforms 38:876-887. https://doi.org/10.1002/ esp.3374

Legros F (2002) The mobility of long-runout landslides. Eng Geol 63: 301-331. https://doi.org/10.1016/S0013-7952(01)00090-4

McColl ST (2012) Paraglacial rock-slope stability. Geomorphology 153154:1-16. https://doi.org/10.1016/j.geomorph.2012.02.015

McColl ST, Davies TRH (2013) Large ice-contact slope movements: glacial buttressing, deformation and erosion. Earth Surf. Process. Landforms 38:1102-1115. https://doi.org/10.1002/esp.3346

Nicolussi K, Patzelt G (2000) Untersuchungen zur Holozänen Gletscherentwicklung von Pasterze und Gepatschferner (Ostalpen). Z Gletscherk Glazialgeol 36:1-87

Okura Y, Kitahara H, Sammori T, Kawanami A (2000) The effects of rockfall volume on runout distance. Eng Geol 58:109-124. https:// doi.org/10.1016/S0013-7952(00)00049-1

Oppikofer T, Jaboyedoff M, Keusen H-R (2008) Collapse at the eastern Eiger flank in the Swiss Alps. Nat Geosci 1:531-535. https://doi. org/10.1038/ngeo258

Oppikofer T, Jaboyedoff M, Pedrazzini A, Derron M-H, Blikra LH (2011) Detailed DEM analysis of a rockslide scar to characterize the basal sliding surface of active rockslides. J Geophys Res 116: 1-22. https://doi.org/10.1029/2010JF001807

Palis E, Lebourg T, Tric E, Malet J-P, Vidal M (2017) Long-term monitoring of a large deep-seated landslide (La Clapiere, south-east French Alps): initial study. Landslides 14:155-170. https://doi.org/ 10.1007/s10346-016-0705-7

Paranunzio R, Laio F, Chiarle M, Nigrelli G, Guzzetti F (2016) Climate anomalies associated to the occurrence of rockfalls at high-elevation in the Italian Alps. Nat Hazards Earth Syst Sci Discuss:1-24. https:// doi.org/10.5194/nhess-2016-100

Patzelt G (1972) Die spätglazialen Stadien und postglazialen Schwankungen von Ostalpengletschern. Ber D Dt Bot Ges 85:4757

Patzelt G (1977) Der zeitliche Ablauf und das Ausmaß postglazialer Klimaschwankungen in den Alpen, In: Dendrochronologie und postglaziale Klimaschwankungen in Europa Frenzel, B., Steiner (eds), Wiesbaden, 248-259

Pfeifer N, Mandlburger G, Otepka J, Karel W (2014) OPALS - a framework for airborne laser scanning data analysis. Comput Environ Urban Syst 45:125-136

Prager C, Zangerl C, Patzelt G, Brandner R (2008) Age distribution of fossil landslides in the Tyrol (Austria) and its surrounding areas. Natural Hazards and Earth System Sciences 8(2):377-407

Piccolruaz C (2004) Zur Quartärgeologie des Kaunertals im Bereich östlich des Gepatsch Stausees in den westlichen Ötztaler Alpen (Tirol) unter besonderer Berücksichtigung der Blockgletscher. Diplomarbeit, University of Innsbruck, Faculty of Geo- and Atmospheric Sciences, Innsbruck

Prager, C. (2010) Geologie, Alter und Struktur des Fernpass Bergsturzes und tiefgründiger Massenbewegungen in seiner Umgebung (Tirol, Österreich). Dissertation, Universität Innsbruck. 309 pp.

Purtscheller F (1987) Ötztaler und Stubaier Alpen, Sammlung geologischer Führer, 53. Gebr. Bornträger, Stuttgart, 128 pp.

Ravanel L, Deline P (2011) Climate influence on rockfalls in high-alpine steep rockwalls: the north side of the aiguilles de Chamonix (Mont Blanc massif) since the end of the "little ice age". The Holocene 21: 357-365. https://doi.org/10.1177/0959683610374887

Reitner JM, Linner M (2009) Formation and preservation of large scale toppling related to alpine tectonic structures eastern Alps. Aust J Earth Sci 102:69-80

Riegl 2013. Operating and Processing Software RiScan Pro. RIEGL LMS

Riva F, Agliardi F, Amitrano D, Crosta GB (2018) Damage-based timedependent modeling of paraglacial to postglacial progressive failure of large rock slopes. J Geophys Res: Earth Surf 123:124-141. https://doi.org/10.1002/2017JF004423

RVS 11.062 (1987) Blatt 10 \& 11 - Prüfverfahren - Steinmaterial, Semiquantitative röntgenographische Mineralanalyse. RDA, Vienna, p 4

Scaioni M, Longoni L, Melillo V, Papini M (2014) Remote sensing for landslide investigations: an overview of recent achievements and perspectives. Remote Sens 6:9600-9652. https://doi.org/10.3390/ rs6109600

Scheidegger AE (1973) On the prediction of the reach and velocity of catastrophic landslides. Rock Mech 5:231-236. https://doi.org/10. 1007/BF01301796

Schmid SM, Fügenschuh B, Kissling E, Schuster R (2004) Tectonic map and overall architecture of the alpine orogeny. Eclogae Geol Helv 97:93-117. https://doi.org/10.1007/s00015-004-1113-x

Strauhal T (2015) Geological, hydrogeological and geotechnical characterisation of deep-seated rockslide in metamorphic rocks. Doctoral thesis, Institute of Geology, University of Innsbruck, $237 \mathrm{pp}$.

Strauhal T, Zangerl C, Fellin W, Holzmann M, Engl DA, Brandner R, Tropper P, Tessadri R (2017) Structure, mineralogy and Geomechanical properties of shear zones of deep-seated rockslides in metamorphic rocks (Tyrol, Austria). Rock Mech Rock Eng 50: 419-438. https://doi.org/10.1007/s00603-016-1113-y

Sturzenegger M, Stead D (2009) Quantifying discontinuity orientation and persistence on high mountain rock slopes and large landslides using terrestrial remote sensing techniques. Nat Hazards Earth Syst Sci 9:267-287. https://doi.org/10.5194/nhess-9-267-2009

Tarini M, Cignoni P, Montani C (2006) Ambient occlusion and edge cueing for enhancing real time molecular visualization. IEEE Trans Vis Comput Graph 12(5):1237-1244. https://doi.org/10. 1109/TVCG.2006.115

van Husen D (1987) Die Ostalpen in den Einszeiten. - Die Ostalpen und ihr Vorland in der Letzten Eiszeit (Würm). Geol. Bundesanstalt, Wien

Weirich J, Bortenschlager S (1980) Beitrage zur Vegetationsgeschichte Tirols III: Stubaier Alpen - Zillertaler Alpen, Berichte naturwiss.mediz. Vereins Innsbruck, vol 67, pp 7-30

Wichmann V, Strauhal T, Fey C, Perzlmaier S (2018) Derivation of spaceresolved normal joint spacing and in-situ block size distribution data from LIDAR point clouds in a rugged alpine relief (Kühtai, Austria). Bull Eng Geol Environ. https://doi.org/10.1007/s10064-018-1374-7

Willenberg H, Loew S, Eberhardt E, Evans KF, Spillmann T, Heincke B, Maurer H, Green AG (2008) Internal structure and deformation of an unstable crystalline rock mass above Randa (Switzerland): part I internal structure from integrated geological and geophysical investigations. Eng Geol 101:1-14

Zangerl C, Prager C (2008) Influence of geological structures on failure initiation, internal deformation and kinematics of rockslides-ARMA 08-063. Proceedings 42nd U.S. / 2nd U.S.-Canada Rock Mechanics Symposium, San Francisco. 13 pp.

Zangerl C, Prager C, Engl D (2010) Self-stabilisation mechanisms of slow rock slides in crystalline bedrock (Tyrol, Austria). In: Williams AL (ed) Geologically active: proceedings of the 11th IAEG congress, Auckland, New Zealand, 5-10 September 2010. CRC Press, Boca Raton, pp 903-910

Zangerl C, Chwatal W, Kirschner H (2015) Formation processes, geomechanical characterisation and buttressing effects at the toe of deep-seated rock slides in foliated metamorphic rock. Geomorphology 243:51-64. https://doi.org/10.1016/j.geomorph. 2015.03.030

Zischinsky U (1966) On the deformation of high slopes. Proceedings of the first congress of the Int. Soc Rock Mech 6:179-185

Zischinsky U (1969) Über Sackungen. Rock Mech 1:30-52 